Article

\title{
Tris(bipyridine)Metal(II)-Templated Assemblies of 3D Alkali-Ruthenium Oxalate Coordination Frameworks: Crystal Structures, Characterization and Photocatalytic Activity in Water Reduction
}

\author{
Alla Dikhtiarenko ${ }^{1, *}$, Pedro Villanueva-Delgado ${ }^{2}$, Rafael Valiente ${ }^{3}$, José R. García ${ }^{1, *}$ \\ and José Gimeno ${ }^{1}$ \\ 1 Organic and Inorganic Chemistry Department, University of Oviedo-CINN, 33006 Oviedo, Spain; \\ jgh@uniovi.es \\ 2 Department of Chemistry and Biochemistry, University of Bern, 3012 Bern, Switzerland; \\ pedro.villanueva@dcb.unibe.ch \\ 3 MALTA Consolider Team, Department of Applied Physic, University of Cantabria, 39005 Santander, Spain; \\ rafael.valiente@unican.es \\ * Correspondence: alla.dikhtiarenko@gmail.com (A.D.); jrgm@uniovi.es (J.R.G.); Tel.: +34-985-105-753 (A.D.); \\ +34-985-103-030 (J.R.G.)
}

Academic Editor: Félix Zamora

Received: 5 January 2016; Accepted: 4 February 2016; Published: 15 February 2016

\begin{abstract}
A series of 3D oxalate-bridged ruthenium-based coordination polymers with the formula of $\left\{\left[\mathrm{Z}^{\mathrm{II}}(\mathrm{bpy})_{3}\right]\left[\mathrm{M}^{\mathrm{I}} \mathrm{Ru}\left(\mathrm{C}_{2} \mathrm{O}_{4}\right)_{3}\right]\right\}_{\mathrm{n}}\left(\mathrm{Z}^{\mathrm{II}}=\mathrm{Zn}^{2+}(\mathbf{1}), \mathrm{Cu}^{2+}(3,4), \mathrm{Ru}^{2+}(5,6), \mathrm{Os}^{2+}(7,8) ; \mathrm{M}^{\mathrm{I}}=\mathrm{Li}^{+}\right.$, $\mathrm{Na}^{+}$; bpy $=2,2^{\prime}$-bipyridine) and $\left\{\left[\mathrm{Zn}^{\mathrm{II}}(\mathrm{bpy})_{3}\right]\left(\mathrm{H}_{2} \mathrm{O}\right)\left[\mathrm{LiRu}\left(\mathrm{C}_{2} \mathrm{O}_{4}\right)_{3}\right]\right\}_{\mathrm{n}}$ (2) has been synthesized at room temperature through a self-assembly reaction in aqueous media and characterized by single-crystal and powder X-ray diffraction, elemental analysis, infrared and diffuse reflectance UV-Vis spectroscopy and thermogravimetric analysis. The crystal structures of all compounds comprise chiral 3D honeycomb-like polymeric nets of the srs-type, which possess triangular anionic cages where $\left[\mathrm{Z}^{\mathrm{II}}(\mathrm{bpy})_{3}\right]^{2+}$ cationic templates are selectively embedded. Structural analysis reveals that the electronic configuration of the cationic guests is affected by electrostatic interaction with the anionic framework. Moreover, the MLCT bands gaps values for 1-8 can be tuned in a rational way by judicious choice of $\left[\mathrm{Z}^{\mathrm{II}}(\mathrm{bpy})_{3}\right]^{2+}$ guests. The 3D host-guest polymeric architectures can be used as self-supported heterogeneous photocatalysts for the reductive splitting of water, exhibiting photocatalytic activity for the evolution of $\mathrm{H}_{2}$ under UV light irradiation.
\end{abstract}

Keywords: water splitting; hydrogen evolution; coordination polymers; photocatalysts

\section{Introduction}

In recent years, the depletion of fossil fuels and the environmental problems caused by their combustion have stimulated research on the development of new renewable energy production technologies. So far, several approaches have been proposed in order to address this challenge. Among those explored, the system combining photocatalysts and solar energy as a clean and abundant energy resource is recognized to be of great promise. Currently, enormous attention has been paid to photocatalytic hydrogen production from water, which is a promising way to produce hydrogen as a potential clean energy source [1,2]. In this line, the hybridization of organic and inorganic materials opens up a new field in the design and preparation of applicable photocatalysts for water splitting reaction by the integration of useful organic and inorganic characteristics within a single composite $[3,4]$. 
In this sense, metal-organic frameworks (MOFs) and coordination polymers (CPs) [5], which are organic-inorganic hybrid materials consisting of organic linkers and metal centers, clusters or metal-oxo clusters, have received great interest due to properties, such as extremely high surface areas, well-ordered porous architectures and structural designability [6,7]. Taking advantage of these interesting properties, MOFs/CPs are widely studied for many potential applications, from gas storage to molecular sieving, ion conductivity and catalysis [8-13]. Additionally, in recent years, an increasing number of studies has demonstrated that MOFs serve as a platform for integrating different functional components to achieve light harvesting [14-16] and to drive various photocatalytic reactions $[17,18]$, such as carbon dioxide reduction to CO [19,20], formic acid [21-23] or methanol [24,25], synthesis of metallic nanoparticles [26] or metallic nanostructures for lithographic pattering [27], oxidation of organic compounds [28-32], degradation of organic dyes [33-37] and various organic transformations [19,38-40]. Compared to the other photocatalytic systems, the MOFs photocatalysts have advantages in that the variety of combinations of bridging organic linkers $[41,42]$ and metallic centers $[43,44]$ allows for the fine-tuning and rational design of these photocatalysts at the molecular level. In this context, recent synthetic achievements have been delivered to robust MOFs/CPs displaying photocatalytic activity in photocatalytic water splitting reaction towards $\mathrm{H}_{2}$ production $[45,46]$.

In 2009, Kataoka et al. firstly applied ruthenium-based MOFs as a heterogeneous catalyst for photo-promoted $\mathrm{H}_{2}$ production [47]. Under VIS light irradiation, the photocatalytic system containing $\left[\mathrm{Ru}^{\mathrm{II}, \mathrm{III}}{ }_{2}(\mathrm{BDC})_{2} \mathrm{BF}_{4}\right]_{\mathrm{n}}$ MOF (BDC = benzene-1,4-dicarboxylate) acting as catalysts, $\left[\mathrm{Ru}(\mathrm{bpy})_{3}\right]^{2+}$ (bpy $=2,2^{\prime}$-bipyridine) as photosensitizer, EDTA (ethylenediaminetetraacetate) and $\mathrm{MV}^{2+}$ ( $N, N^{\prime}$-dimethyl-4,4'-bipyridinium) as electron donors was able to photo-split water molecules, generating $\mathrm{H}_{2}$ with high rates. Later, this study was extended on a series of analogous $\left[\mathrm{Ru}^{\mathrm{II}, \mathrm{III}}{ }_{2}(\mathrm{BDC})_{2} \mathrm{X}\right]_{\mathrm{n}}\left(\mathrm{X}=\mathrm{BF}^{4-}, \mathrm{Cl}^{-}, \mathrm{Br}^{-}\right) \mathrm{MOF}$ s based on the diruthenium paddle-well structural units, with an attempt to determine the effect of the incorporated anion on the photocatalytic behavior of the materials [48]. Among more recent studies, the photocatalytic activity of $\mathrm{NH}_{2}-\mathrm{MOF}-\mathrm{Ti}[49,50]$ and $\mathrm{NH}_{2}-\mathrm{UiO}-66(\mathrm{Zr})[51]$ was improved through post-synthetic deposition within the framework of $\mathrm{Pt}$ nanoparticles, which in turn behave as co-catalysts in a reductive water splitting reaction. Similarly, the MIL-101(Cr) MOF with embedded CdS nanoparticles shows high catalytic activity towards $\mathrm{H}_{2}$ generation upon VIS light [52]. Moreover, several photocatalytic MOFs for hydrogen evolution were prepared via post-modification of organic linkers incorporating photosensitizer molecule or a photoactive complex, such as in the case of the UiO-66(Zr) framework sensitized with rhodamine B [53], UiO-67(Zr) with the target $\left[\operatorname{Ir}(\mathrm{ppy})_{2}(\mathrm{bpy})\right]^{+}$(ppy $=2$-phenylpyridine, bpy $=2,2^{\prime}$-bipyridine) complex [54], MOF-253(Al) with the post-synthetically-immobilized Pt-complex [55] or UiO-66(Zr) with [[FeFe]-(dcbdt)(CO) 6 ] (dcbdt $=1$,4-dicarboxylbenzene-2,3-dithiolate) -loaded functional groups [56]. Moreover, due to the complex, laborious and multistep way of post-synthetic functionalization, several photocatalytically-active MOFs/CPs for hydrogen evolution were obtained through the easiest one-pot syntheses; for instance, $\left\{\left[\mathrm{Ln}_{2} \mathrm{Cu}_{5}(\mathrm{OH})_{2}(\text { pydc })_{6}\left(\mathrm{H}_{2} \mathrm{O}\right)_{8}\right] \cdot \mathrm{I}_{8}\right\}_{\mathrm{n}}(\mathrm{Ln}=\mathrm{Sm}, \mathrm{Eu}, \mathrm{Gd}$ and $\mathrm{Tb})$ MOF templated by iodine anions [57], polyoxometalate-based $\left\{(\mathrm{TBA})_{2}\left[\mathrm{Cu}{ }^{\mathrm{II}}(\mathrm{BBTZ})_{2}\left(x-\mathrm{Mo}_{8} \mathrm{O}_{26}\right)\right]\right\}_{\mathrm{n}}$ (TBA $=$ tetrabutylammonium cation; $\mathrm{BBTZ}=1,4$-bis(1,2,4-triazol-1ylmethyl)-benzene; $x=\beta$ and $\alpha)$ anionic frameworks [58] or porphyrin-based $\left\{[\mathrm{Al}(\mathrm{OH})]_{2} \mathrm{H}_{2} \mathrm{TCPP}\left(\mathrm{DMF}_{3}-\left(\mathrm{H}_{2} \mathrm{O}\right)_{2}\right\}_{\mathrm{n}}\left(\mathrm{H}_{2} \mathrm{TCPP}=\right.\right.$ tetra(4-carboxyl-phenyl)porphyrin) [59]. Recently, Nasalevich et al. reported another approach for efficient visible light $\mathrm{H}_{2}$ evolution via a ship in a bottle strategy [60].

Regarding the benefits of one-pot synthesis paths for the preparation of photocatalytically-active $\mathrm{MOF} / \mathrm{CPs}$ and taking into account the potential disadvantages of post-synthetic approaches, such as inhomogeneous distribution and functionalization degrees, we envisioned that known host-guest oxalate-bridged 3D frameworks with the general formula of $\left\{\left[\mathrm{Z}^{\mathrm{II}}(\mathrm{bpy})_{3}\right]\left[\mathrm{M}^{\mathrm{I}} \mathrm{M}^{\mathrm{III}}\left(\mathrm{C}_{2} \mathrm{O}_{4}\right)_{3}\right]\right\}_{\mathrm{n}}$ (where the $\mathrm{Z}^{\mathrm{II}}: \mathrm{M}^{\mathrm{I}}: \mathrm{M}^{\mathrm{III}}$ metal combinations known are $\mathrm{Fe}^{2+}: \mathrm{Li}^{+}: \mathrm{Cr}^{3+}, \mathrm{Fe}^{2+}: \mathrm{Na}^{+}: \mathrm{Cr}^{3+}, \mathrm{Fe}^{2+}: \mathrm{Li}^{+}: \mathrm{Fe}^{3+}$, $\mathrm{Fe}^{2+}: \mathrm{Na}^{+}: \mathrm{Fe}^{3+}, \mathrm{Zn}^{2+}: \mathrm{Na}^{+}: \mathrm{Al}^{3+}, \mathrm{Zn}^{2+}: \mathrm{Na}^{+}: \mathrm{Cr}^{3+}, \mathrm{Ru}^{2+}: \mathrm{Na}^{+}: \mathrm{Al}^{3+}, \mathrm{Ru}^{2+}: \mathrm{Li}^{+}: \mathrm{Cr}^{3+}, \mathrm{Ru}^{2+}: \mathrm{Na}^{+}: \mathrm{Cr}^{3+}$, 
$\left.\mathrm{Ru}^{2+}: \mathrm{Na}^{+}: \mathrm{Rh}^{3+}, \quad \mathrm{Co}^{2+}: \mathrm{Na}^{+}: \mathrm{Cr}^{3+}, \quad \mathrm{Co}^{2+}: \mathrm{Li}^{+}: \mathrm{Cr}^{3+}, \quad \mathrm{Ni}^{2+}: \mathrm{Na}^{+}: \mathrm{Al}^{3+}, \quad \mathrm{Os}^{2+}: \mathrm{Na}^{+}: \mathrm{Al}^{3+}\right) \quad$ [61-70], $\left\{\left[\mathrm{Z}^{\mathrm{II}}(\mathrm{bpy})_{3}\right]\left(\mathrm{H}_{2} \mathrm{O}\right)\left[\mathrm{M}^{\mathrm{I}} \mathrm{M}^{\mathrm{III}}\left(\mathrm{C}_{2} \mathrm{O}_{4}\right)_{3}\right]\right\}_{\mathrm{n}}$ (where the $\mathrm{Z}^{\mathrm{II}}: \mathrm{M}^{\mathrm{I}}: \mathrm{M}^{\mathrm{III}}$ metal combinations known are $\mathrm{Ni}^{2+}: \mathrm{Li}^{+}: \mathrm{Cr}^{3+}$ and $\left.\mathrm{Ru}^{2+}: \mathrm{Li}^{+}: \mathrm{Cr}^{3+}\right)[71],\left\{\left[\mathrm{Z}^{\mathrm{III}}(\mathrm{bpy})_{3}\right](\mathrm{X})\left[\mathrm{M}^{\mathrm{I}} \mathrm{M}^{\mathrm{III}}\left(\mathrm{C}_{2} \mathrm{O}_{4}\right)_{3}\right]\right\}_{\mathrm{n}}$ (where $\mathrm{X}=\mathrm{ClO}_{4}{ }^{-}, \mathrm{PF}_{6}{ }^{-}, \mathrm{BF}_{4}{ }^{-}$; bpy $=2,2^{\prime}$-bipyridine; the $Z^{\mathrm{III}}: \mathrm{M}^{\mathrm{I}}: \mathrm{M}^{\mathrm{III}}$ metal combinations known are $\mathrm{Rh}^{3+}: \mathrm{Na}^{+}: \mathrm{Cr}^{3+}, \mathrm{Rh}^{3+}: \mathrm{Na}^{+}: \mathrm{Al}^{3+}$, $\left.\mathrm{Rh}^{3+}: \mathrm{Na}^{+}: \mathrm{Rh}^{3+}, \mathrm{Cr}^{3+}: \mathrm{Na}^{+}: \mathrm{Cr}^{3+}, \mathrm{Cr}^{3+}: \mathrm{Na}^{+}: \mathrm{Al}^{3+}, \mathrm{Cr}^{3+}: \mathrm{Na}^{+}: \mathrm{Rh}^{3+}, \mathrm{Co}^{3+}: \mathrm{Na}^{+}: \mathrm{Cr}^{3+}\right)[62,63,70,72-76]$ could be positioned as deserving competitors along with those functional MOFs that encapsulate photoactive guest molecules in the pores of the framework [77]. In this class of compounds, the $\left[\mathrm{Z}^{\mathrm{II}}(\mathrm{bpy})_{3}\right]^{2+}$ cations tightly fit into vacant cavities provided by the three-dimensional anionic $\left\{\left[\mathrm{M}^{\mathrm{I}} \mathrm{M}^{\mathrm{III}}\left(\mathrm{C}_{2} \mathrm{O}_{4}\right)_{3}\right]^{2-}\right\}_{\mathrm{n}}$ network. Thereby, tris-bipyridine complexes are quantitatively and homogeneously distributed within the polymeric framework. Moreover, the chemical variation and combination of the metal ions in the oxalate backbone, as well as in the tris-bipyridine cation offer unique opportunities for the rational design of a photoactive coordination polymer with the desired photochemical and photophysical properties, such as light-induced electron transfer and excitation energy transfer in the solid state.

Thus, herein, we present the synthesis of a series of new three-dimensional ruthenium-based oxalate-bridged anionic networks $\left\{\left[\mathrm{M}^{\mathrm{I}} \mathrm{Ru}^{\mathrm{III}}\left(\mathrm{C}_{2} \mathrm{O}_{4}\right)_{3}\right]^{2-}\right\}_{\mathrm{n}}\left(\mathrm{M}^{\mathrm{I}}=\mathrm{Na}^{+}, \mathrm{Li}^{+}\right)$in which the large honeycombed channels are occupied by $\left[\mathrm{Z}^{\mathrm{II}}(\mathrm{bpy})_{3}\right]^{2+}\left(\mathrm{bpy}=2,2^{\prime}\right.$-bipyridine, $\mathrm{Z}^{\mathrm{II}}=\mathrm{Zn}^{2+}, \mathrm{Cu}^{2+}, \mathrm{Ru}^{2+}$, $\mathrm{Os}^{2+}$ ) cationic templates. In addition to a thorough structural characterization, we demonstrate the high photocatalytic activity of these structured solids.

\section{Materials and Methods}

\subsection{Materials}

The complexes $\left[\mathrm{Z}^{\mathrm{II}}(\mathrm{bpy})_{3}\right]\left(\mathrm{ClO}_{4}\right)_{2}\left(\right.$ where $\left.\mathrm{Z}^{\mathrm{II}}=\mathrm{Zn}^{2+}, \mathrm{Cu}^{2+}, \mathrm{Ru}^{2+}\right),\left[\mathrm{Os}^{\mathrm{II}}(\mathrm{bpy})_{3}\right]\left(\mathrm{PF}_{6}\right)_{2}$ and $\mathrm{K}_{3}\left[\mathrm{Ru}\left(\mathrm{C}_{2} \mathrm{O}_{4}\right)_{3}\right] \cdot 4.5 \mathrm{H}_{2} \mathrm{O}$ were prepared according to the literature methods [78-80]. The other chemicals are commercially available and were used as purchased.

2.2. Synthesis of the $\left\{\left[\mathrm{Z}^{\mathrm{II}}(\mathrm{bpy})_{3}\right]\left[\mathrm{NaRu}\left(\mathrm{C}_{2} \mathrm{O}_{4}\right)_{3}\right]\right\}_{n}\left(\mathrm{Z}^{\mathrm{II}}=\mathrm{Zn}^{2+}(\mathbf{1}), \mathrm{Cu}^{2+}(3), \mathrm{Ru}^{2+}(5), \mathrm{Os}^{2+}(7)\right)$, $\left\{\left[\mathrm{Z}^{\mathrm{II}}(\mathrm{bpy})_{3}\right]\left[\mathrm{LiRu}\left(\mathrm{C}_{2} \mathrm{O}_{4}\right)_{3}\right]\right\}_{n}\left(\mathrm{Z}^{\mathrm{II}}=\mathrm{Cu}^{2+}(\mathbf{4}), \mathrm{Ru}^{2+}(\mathbf{6}), \mathrm{Os}^{2+}(8)\right)$ and $\left\{\left[\mathrm{Zn}(\mathrm{bpy})_{3}\right]\left(\mathrm{H}_{2} \mathrm{O}\right)\left[\mathrm{LiRu}\left(\mathrm{C}_{2} \mathrm{O}_{4}\right)_{3}\right]\right\}_{n}$ (2) Series of Compounds

The synthesis process was performed in accordance with a previously-published procedure for the $\left\{\left[\mathrm{Fe}^{\mathrm{II}}(\mathrm{bpy})_{3}\right]\left[\mathrm{M}^{\mathrm{I}} \mathrm{Cr}\left(\mathrm{C}_{2} \mathrm{O}_{4}\right)_{3}\right]\right\}$ (where $\left.\mathrm{M}^{\mathrm{I}}=\mathrm{Na}^{+}, \mathrm{Li}^{+}\right)$compounds [61] introducing the $\left[\mathrm{Ru}\left(\mathrm{C}_{2} \mathrm{O}_{4}\right)_{3}\right]^{3-}$ moiety instead of $\left[\mathrm{Cr}\left(\mathrm{C}_{2} \mathrm{O}_{4}\right)_{3}\right]^{3-}$. In a typical synthesis, $141 \mathrm{mg}(0.25 \mathrm{mmol})$ of $\mathrm{K}_{3}\left[\mathrm{Ru}\left(\mathrm{C}_{2} \mathrm{O}_{4}\right)_{3}\right] \cdot 4.5 \mathrm{H}_{2} \mathrm{O}$ and $30 \mathrm{mg}(0.5 \mathrm{mmol})$ of $\mathrm{NaCl}$ or $20 \mathrm{mg}(0.5 \mathrm{mmol})$ of $\mathrm{LiCl}$ were dissolved in $5 \mathrm{~mL}$ of water, and $0.25 \mathrm{mmol}$ of the $\left[\mathrm{Z}^{\mathrm{II}}(\mathrm{bpy})_{3}\right]\left(\mathrm{ClO}_{4}\right)_{2}$ salt $\left(\left[\mathrm{Zn}^{\mathrm{II}}(\mathrm{bpy})_{3}\right]\left(\mathrm{ClO}_{4}\right)_{2}, 183 \mathrm{mg}\right.$; $\left[\mathrm{Cu}^{\mathrm{II}}(\mathrm{bpy})_{3}\right]\left(\mathrm{ClO}_{4}\right)_{2}, 183 \mathrm{mg}$; $\left[\mathrm{Ru}^{\mathrm{II}}(\mathrm{bpy})_{3}\right]\left(\mathrm{ClO}_{4}\right)_{2}, 192 \mathrm{mg}$; $\left.\left[\mathrm{Os}^{\mathrm{II}}(\mathrm{bpy})_{3}\right]\left(\mathrm{PF}_{6}\right)_{2}, 237 \mathrm{mg}\right)$ dissolved in a water/ethanol mixture were added dropwise; after few minutes, precipitates appeared, and the suspensions were stirred for $1 \mathrm{~h}$. The resulting precipitates were filtered, washed with ethanol and air dried.

Yellow precipitates of 1 and 2 yield $90 \%$ and $74 \%$, respectively. Anal. Calc. for $\mathrm{C}_{36} \mathrm{H}_{24} \mathrm{~N}_{6} \mathrm{NaO}_{12} \mathrm{RuZn}(1): \mathrm{C}, 46.85 \% ; \mathrm{H}, 2.60 \%$; N, 9.11\%. Found: C, 47.0\%; H, 2.85\%; N, 9.1\%. Anal. Calc. for $\mathrm{C}_{36} \mathrm{H}_{26} \mathrm{LiN}_{6} \mathrm{O}_{13} \mathrm{RuZn}$ (2): C, $46.75 \%$; H, 2.81\%; N, 9.09\%. Found: C, 46.8\%; H, 2.9\%; $\mathrm{N}, 9.1 \%$.

Greenish precipitates of 3 and 4 yield $81 \%$ and $77 \%$, respectively. Anal. Calc. for $\mathrm{C}_{36} \mathrm{H}_{24} \mathrm{CuN}_{6} \mathrm{NaO}_{12} \mathrm{Ru}(3): \mathrm{C}, 46.94 \% ; \mathrm{H}, 2.83 \% ; \mathrm{N}, 9.13 \%$. Found: C, 50.0\%; H, 2.9\%; N, 9.2\%. Anal. Calc. for $\mathrm{C}_{36} \mathrm{H}_{24} \mathrm{CuLiN}_{6} \mathrm{O}_{12} \mathrm{Ru}(4)$ : $\mathrm{C}, 47.78 \% ; \mathrm{H}, 2.87 \%$; N, 9.29\%. Found: $\mathrm{C}, 47.8 \% ; \mathrm{H}, 2.9 \%$; N, 9.3\%.

Red-orange precipitates of 5 and 6 yield $62 \%$ and $78 \%$, respectively. Anal. Calc. for $\mathrm{C}_{36} \mathrm{H}_{24} \mathrm{~N}_{6} \mathrm{NaO}_{12} \mathrm{Ru}_{2}$ (5): $\mathrm{C}, 45.11 \% ; \mathrm{H}, 2.51 \% ; \mathrm{N}, 8.77 \%$. Found: $\mathrm{C}, 45.0 \% ; \mathrm{H}, 2.7 \% ; \mathrm{N}, 8.8 \%$. Anal. Calc. for $\mathrm{C}_{36} \mathrm{H}_{24} \mathrm{LiN}_{6} \mathrm{O}_{12} \mathrm{Ru}_{2}$ (6): C, 45.87\%; H, 2.55\%; N, 8.92\%. Found: $\mathrm{C}, 46.5 \% ; \mathrm{H}, 2.8 \%$; N, 9.2\%.

Dark green precipitates of 7 and 8 yield $54 \%$ and $68 \%$, respectively. Anal. Calc. for $\mathrm{C}_{36} \mathrm{H}_{24} \mathrm{~N}_{6} \mathrm{NaO}_{12} \mathrm{OsRu}$ (7): C, 41.26\%; H, 2.29\%; N, 8.02\%. Found: C, 41.4\%; H, 2.3\%; N, 8.2\%. Anal. Calc. for $\mathrm{C}_{36} \mathrm{H}_{24} \mathrm{LiN}_{6} \mathrm{O}_{12} \mathrm{OsRu}(8)$ : C, $41.91 \%$; H, 2.33\%; N, 8.15\%. Found: C, $42.1 \%$; H, $2.3 \%$; N, 8.3\%. 


\subsection{X-Ray Structure Determinations}

Tetrahedral-shaped single crystals of Compounds 1-8 (Figure S1) were selected for single-crystal $X$-ray diffraction analyses. The intensity data were collected at room temperature on an Oxford-Gemini X-ray diffractometer using for Compounds 2 and 4 graphite-monochromatic Mo-K $\alpha(\lambda=0.71073 \AA)$ and for $1,3,5-8, C u-K \alpha(\lambda=1.54184 \AA)$ radiation. The CrysAlisPro software was used for cell refinement and data reduction. Images were collected at a 55-mm fixed crystal-detector distance, using the oscillation method, with 1 oscillation and variable exposure time per image. The structures were solved by direct methods using the SIR92 program [81]. The refinement was performed by SHELX-97 using full-matrix least squares on $F^{2}$ [82]. All non-H atoms were anisotropically refined. The hydrogen atoms of the 2,2'-bipyridine ligand were placed geometrically, and the hydrogen atoms of the water molecule in Compound $\mathbf{2}$ could not be located, but were included in the formula. Flack's absolute parameter $(x)$ was used to determine the space group of compounds [83]. Crystallographic data for 1-8 (CCDC\#1404961-1404964,\#1404970-1404973) have been deposited with Cambridge Crystallographic Data Centre. The detailed crystallographic data are summarized in Table S1 (Supplementary Materials). Topological and geometrical analysis of 1-8 was obtained using TOPOS 4.0 software [84]. X-ray powder diffraction patterns were collected with a X'Pert Philips X-ray diffractometer (CuK $\alpha$ radiation, $\lambda=1.5418 \AA$ ) at room temperature. The powder diffraction patterns indicate that all compounds are isostructural and show analogous patterns to the simulated patterns from the atomic coordinates of the crystal structures of 1-8 (Figures S2-S5, Supplementary Materials).

\subsection{Characterization Methods}

The IR spectra were recorded on a Bruker Tensor-27 spectrophotometer as $\mathrm{KBr}$ pellets in the $4000-500 \mathrm{~cm}^{-1}$ region. Microanalyses (C, H, N) were carried out by the use of a Perkin-Elmer model 2400B elemental analyzer. X-ray microanalysis (SEM/EDX) confirmed the ratio Ru: $Z^{\mathrm{II}}$ to be 1:1 $\left(\mathrm{Z}^{\mathrm{II}}=\mathrm{Zn}^{2+}, \mathrm{Cu}^{2+}, \mathrm{Os}^{2+}\right)$, by using JEOL JSM-6100 scanning microscopy (SEM) coupled with an INCA Energy-200 dispersive X-ray microanalysis system (EDX) with a PentaFET ultrathin window detector. As shown in Figure S6 (Supplementary Materials), the microcrystalline texture of the samples consists of microcrystals that repeat the same habit as those obtained single crystals, indicating that powder products have been obtained as pure phases. A Mettler-Toledo TGA/SDTA851 was used for the thermal analyses in a nitrogen and air dynamic atmosphere $(50 \mathrm{~mL} / \mathrm{min})$ at a heating rate of $10^{\circ} \mathrm{C} / \mathrm{min}$. Approximately $10 \mathrm{mg}$ of powder sample were thermally treated, and blank runs were performed. A Pfeiffer Vacuum TermoStar ${ }^{\mathrm{TM}}$ GSD301T mass spectrometer was used to determine the evacuated vapors. The masses $15\left(\mathrm{NH}_{3}\right), 18\left(\mathrm{H}_{2} \mathrm{O}\right), 44\left(\mathrm{CO}_{2}\right)$ and $46\left(\mathrm{NO}_{2}\right)$ were tested by using a detector C-SEM, operating at $1200 \mathrm{~V}$, with a time constant of $1 \mathrm{~s}$. A Cary 6000i (Varian) spectrophotometer was used to measure diffuse reflectance spectra in the range $200-1800 \mathrm{~nm}$ using a polytetrafluoroethylene (PTFE)-coated integrating sphere.

\subsection{Photocatalytic Hydrogen Evolution}

Reactions were carried out at room temperature in a $100-\mathrm{mL}$ gastight cell that was custom-designed in order to allow purging and irradiation of the suspension. The gastight cell was a 100-mL two-necked, flat-bottomed flask with a water refrigerator. The cell volume was $100 \mathrm{~mL}$, of which gases occupied $83 \mathrm{~mL}$. In each experiment, $10 \mu \mathrm{mol}$ of heterogeneous catalyst were dispersed in a mixture containing $10 \mathrm{~mL} \mathrm{H}_{2} \mathrm{O}$ and $7 \mathrm{~mL}$ TEA (triethylamine). Reaction mixtures were deoxygenated with three cycles of evacuation and purging with argon. The samples' solutions were illuminated with UV light at room temperature by a 500-W mercury lamp (HELIOS ITALQUARTZ Apparatus, Model UV50F-85P503I5, $\leqslant 366 \mathrm{~nm}$ ) for $12 \mathrm{~h}$. During reaction, magnetic stirring was used to prevent sedimentation of the catalyst. For experiments performed with visible light irradiation, the xenon lamp $(150 \mathrm{~W}, \geqslant 417 \mathrm{~nm})$ was used as the light source. Reaction products were analyzed by mass spectrometry taking regular aliquots $(0.5 \mathrm{~mL})$ of the reactor headspace gas through a septum using a gastight syringe. 
Mass spectrometry analyses were performed using an OmniStar ${ }^{\mathrm{TM}}$ (Pfeiffer Vacuum) gas analysis module connected to AutoChem II 2920 (Micromeritics) catalyst characterization system. A cold trap was used with Ar as the carrier gas. Each gas aliquot was quantified using the calibration graph, which had been previously obtained using standard $10 \%(v / v) \mathrm{H}_{2}$ in $\mathrm{Ar}$ and $5 \%(v / v) \mathrm{O}_{2}$ in He gas mixtures (Air Liquid, Paris, France).

\section{Results and Discussion}

\subsection{Crystal Structures}

Compounds 1-8 present the 3D three-connected decagon oxalate-bridged anionic network $\left\{\left[\mathrm{M}^{\mathrm{I}} \mathrm{Ru}\left(\mathrm{C}_{2} \mathrm{O}_{4}\right)_{3}\right]^{2-}\right\}_{\mathrm{n}}\left(\mathrm{M}^{\mathrm{I}}=\mathrm{Na}^{+}, \mathrm{Li}^{+}\right)$, with the cationic complex $\left[\mathrm{Z}^{\mathrm{II}}(\mathrm{bpy})_{3}\right]^{2+}$ (where $\mathrm{Z}^{\mathrm{II}}=\mathrm{Zn}^{2+}$, $\mathrm{Cu}^{2+}, \mathrm{Ru}^{2+}, \mathrm{Os}^{2+}$; bpy $=2,2^{\prime}$-bipyridine) acting as the template. The single-crystal X-ray analysis of ruthenium-based 3D oxalate bridged polymers reveals that the CPs 1, 3-8 are isostructural with the $\left\{\left[Z^{\mathrm{II}}(\mathrm{bpy})_{3}\right]\left[\mathrm{M}^{\mathrm{I}} \mathrm{M}^{\mathrm{III}}\left(\mathrm{C}_{2} \mathrm{O}_{4}\right)_{3}\right]\right\}_{\mathrm{n}}\left(\mathrm{Z}^{\mathrm{II}}=\mathrm{Co}^{2+}, \mathrm{Zn}^{2+}, \mathrm{Ni}^{2+}, \mathrm{Fe}^{2+}, \mathrm{Ru}^{2+} ; \mathrm{M}^{\mathrm{I}}=\mathrm{Na}^{+}, \mathrm{Li}^{+} ; \mathrm{M}^{\mathrm{III}}=\mathrm{Rh}^{3+}\right.$, $\left.\mathrm{Ru}^{3+}, \mathrm{Al}^{3+}, \mathrm{Cr}^{3+}, \mathrm{Fe}^{3+}\right)$ family of compounds [61-70]. However, Compound 2 is isomorphic with the $\left\{\left[\mathrm{Z}^{\mathrm{II}}(\mathrm{bpy})_{3}\right]\left(\mathrm{H}_{2} \mathrm{O}\right)\left[\mathrm{LiCr}\left(\mathrm{C}_{2} \mathrm{O}_{4}\right)_{3}\right]\right\}_{\mathrm{n}}\left(\mathrm{Z}^{\mathrm{II}}=\mathrm{Ni}^{2+}, \mathrm{Ru}^{2+}\right)$ family of 3D oxalate networks [71].

The detailed crystal data and structure determination parameters of ruthenium-based coordination polymers 1-8 are summarized in Table S1. The CPs 1-8 crystalize in the cubic chiral space group $P 2{ }_{1} 3$ with the asymmetric unit consisting of a complete oxalate ligand, the $\mathrm{Ru}^{3+}$ and $\mathrm{Na}^{+} / \mathrm{Li}^{+}$ ions of the anionic network, the $\mathrm{Z}^{\mathrm{II}}$ metal center $\left(\mathrm{Z}^{\mathrm{II}}=\mathrm{Zn}^{2+}, \mathrm{Cu}^{2+}, \mathrm{Ru}^{2+}, \mathrm{Os}^{2+}\right)$ and the complete bpy ligand of the cationic template (Figure S7a). Each $\mathrm{Ru}^{3+}$ and $\mathrm{Na}^{+} / \mathrm{Li}^{+}$ion is surrounded by six oxygen atoms of the oxalate ligand forming a distorted octahedral coordination environment (Figure 1a,b,d,e) with the mean $\mathrm{Ru}-\mathrm{O}$ and $\mathrm{Na} / \mathrm{Li}-\mathrm{O}$ bond lengths, which are within the range observed for analogous compounds [65].
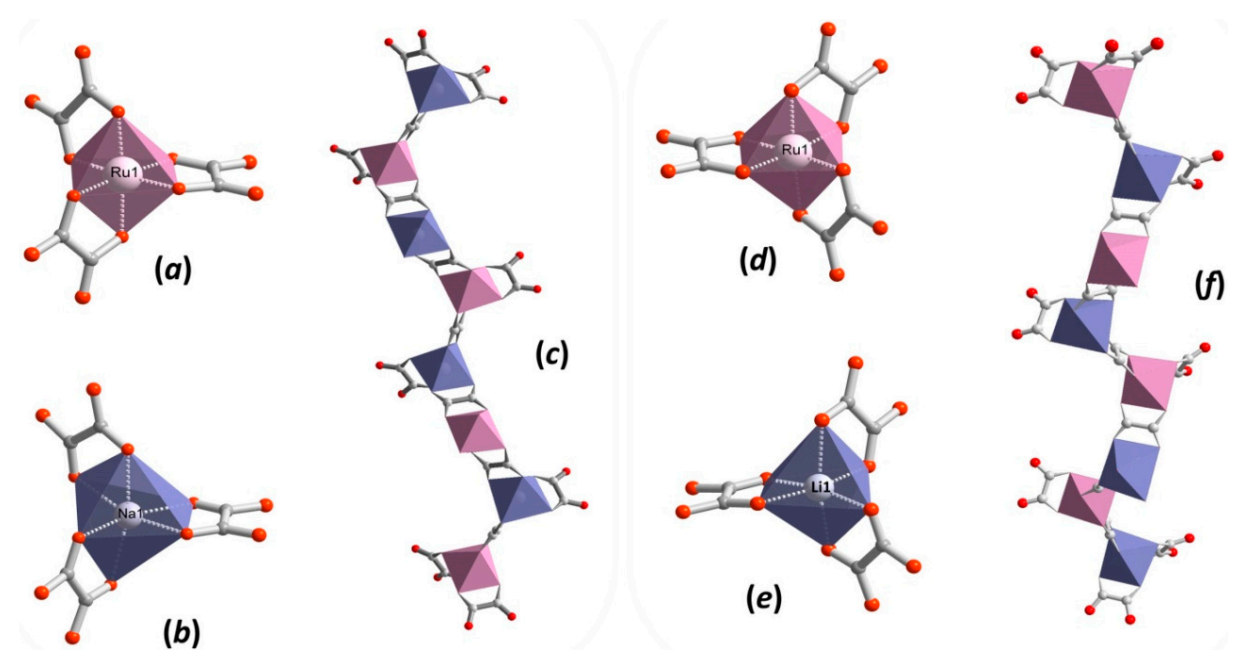

Figure 1. Representation of octahedral coordination environments of (a) $\mathrm{Ru}^{\mathrm{III}}$ and $(\mathbf{b}) \mathrm{Na}^{\mathrm{I}}$ in $\mathbf{1}$ exhibiting $\Lambda$-conformation with the corresponding (c) left-handed helix substructure formed. Representation of octahedral coordination environments of (d) $\mathrm{Ru}^{\mathrm{III}}$ and (e) $\mathrm{Li}^{\mathrm{I}}$ in $\mathbf{1}$ exhibiting $\Delta$-conformation with the corresponding (f) right-handed helix substructure formed. Red and grey spheres represent oxygen and carbon atoms, respectively.

Selected bond distances and distortion parameters of $\mathrm{Ru}^{\mathrm{III}}, \mathrm{Z}^{\mathrm{II}}$ and $\mathrm{M}^{\mathrm{I}}$ coordination environments for Compounds 1-8 are given in Table 1. Interestingly, the $\left\{\mathrm{Ru}\left(\mathrm{C}_{2} \mathrm{O}_{4}\right)_{3}\right\}$ and $\left\{\mathrm{M}^{\mathrm{I}}\left(\mathrm{C}_{2} \mathrm{O}_{4}\right)_{3}\right\}$ structural units (SBU) manifest the same $\Delta$ or $\Lambda$-configuration in the chiral 3D anionic networks (Figure 1a,b,d,e). Thus, Compounds 1, 4-6 and 8 build SBU with the $\Lambda$-form configuration, while 2-3 and 7 are constructed with the $\Delta$-form. 
In this type of structure, the oxalate ligand exhibiting $\mu$-coordination mode (Figure S7b) links in an alternate manner $\mathrm{Ru}^{3+}$ and $\mathrm{Na}^{+} / \mathrm{Li}^{+}$metal centers to form helical substructures, where $\mathrm{Ru} \cdots \mathrm{Na} / \mathrm{Li}$ distances ranged from 5.46-5.63 A. As shown in Figure 1c,f, helical substructures with three-fold axis interpretation spread along the $b$-axis and, depending on the $\left\{\mathrm{Ru}\left(\mathrm{C}_{2} \mathrm{O}_{4}\right)_{3}\right\}$ and $\left\{\mathrm{M}^{\mathrm{I}}\left(\mathrm{C}_{2} \mathrm{O}_{4}\right)_{3}\right\}$ SBUs' conformations $(\Delta$ or $\Lambda$ ), exhibit left- or right-handed rotation. Repeatedly connected adjacent helices form a porous anionic 3D framework with honeycomb-like channels running along the [111] crystallographic direction (Figure 2a). According to topological analysis performed using TOPOS 4.0 software [84], resulting 3D anionic networks are three-connected uninodal nets with a $10^{3}-a$ array topology (Figure 2b; also denoted as the srs-type net) [85].

Table 1. Selected bond length $(\AA)$ for $\left\{\left[\mathrm{Z}^{\mathrm{II}}(\mathrm{bpy})_{3}\right]\left[\mathrm{NaRu}\left(\mathrm{C}_{2} \mathrm{O}_{4}\right)_{3}\right]\right\}_{\mathrm{n}}\left(\mathrm{Z}^{\mathrm{II}}=\mathrm{Zn}^{2+}(\mathbf{1}), \mathrm{Cu}^{2+}(\mathbf{3}), \mathrm{Ru}^{2+}\right.$ (5), $\left.\mathrm{Os}^{2+}(7)\right),\left\{\left[\mathrm{Zn}^{\mathrm{II}}(\mathrm{bpy})_{3}\right]\left(\mathrm{H}_{2} \mathrm{O}\right)\left[\mathrm{LiRu}\left(\mathrm{C}_{2} \mathrm{O}_{4}\right)_{3}\right]\right\}_{\mathrm{n}}(2)$ and $\left.\left[\mathrm{Z}^{\mathrm{II}}(\mathrm{bpy})_{3}\right]\left[\mathrm{LiRu}\left(\mathrm{C}_{2} \mathrm{O}_{4}\right)_{3}\right]\right\}_{\mathrm{n}}\left(\mathrm{Z}^{\mathrm{II}}=\mathrm{Cu}^{2+}(4)\right.$, $\left.\mathrm{Ru}^{2+}(6), \mathrm{Os}^{2+}(8)\right)$ coordination polymers; the configuration and structural distortion parameters of $\left[\mathrm{Z}^{\mathrm{II}}(\mathrm{bpy})_{3}\right]^{2+}\left(\mathrm{Z}^{\mathrm{II}}=\mathrm{Zn}^{2+}, \mathrm{Cu}^{2+}, \mathrm{Ru}^{2+}, \mathrm{Os}^{2+}\right)$ guests compared to the corresponding $\left[\mathrm{Z}^{\mathrm{II}}(\mathrm{bpy})_{3}\right]^{2+}$ cation in salts ${ }^{1}$.

\begin{tabular}{|c|c|c|c|c|c|c|c|c|}
\hline \multirow{2}{*}{$\begin{array}{c}\text { Compound } \\
\text { Bonds }\end{array}$} & \multicolumn{2}{|c|}{$\begin{array}{c}1-2 \\
{\left[\mathrm{Zn}(\mathrm{bpy})_{3}\right]^{2+}}\end{array}$} & \multicolumn{2}{|c|}{$\begin{array}{c}3-4 \\
{\left[\mathrm{Cu}(\mathrm{bpy})_{3}\right]^{2+}}\end{array}$} & \multicolumn{2}{|c|}{$\begin{array}{c}5-6 \\
{\left[\operatorname{Ru}(\mathrm{bpy})_{3}\right]^{2+}}\end{array}$} & \multicolumn{2}{|c|}{$\begin{array}{c}7-8 \\
{\left[\mathrm{Os}(\mathrm{bpy})_{3}\right]^{2+}}\end{array}$} \\
\hline & $\mathrm{M}^{\mathrm{I}}=\mathrm{Na}$ & $\begin{array}{c}\mathrm{M}^{\mathrm{I}}=\mathrm{Li} \\
\left(\mathrm{H}_{2} \mathrm{O}\right)\end{array}$ & $\mathrm{M}^{\mathrm{I}}=\mathrm{Na}$ & $\mathrm{M}^{\mathrm{I}}=\mathrm{Li}$ & $\mathrm{M}^{\mathrm{I}}=\mathrm{Na}$ & $\mathrm{M}^{\mathrm{I}}=\mathrm{Li}$ & $\mathrm{M}^{\mathrm{I}}=\mathrm{Na}$ & $\mathrm{M}^{\mathrm{I}}=\mathrm{Li}$ \\
\hline $\mathrm{Ru}-\mathrm{O} 1$ & $2.013(7)$ & $2.047(3)$ & $2.017(3)$ & $2.034(2)$ & $2.021(3)$ & $2.029(2)$ & $2.027(5)$ & $2.038(4)$ \\
\hline $\mathrm{Ru}-\mathrm{O} 2$ & $2.036(5)$ & $2.050(3)$ & $2.030(3)$ & $2.044(2)$ & $2.023(3)$ & $2.043(3)$ & $2.045(5)$ & $2.049(4)$ \\
\hline $\mathrm{M}^{\mathrm{I}}-\mathrm{O} 3$ & $2.336(9)$ & $2.110(9)$ & $2.336(4)$ & $2.136(6)$ & $2.319(4)$ & $2.214(4)$ & $2.306(6)$ & $2.140(9)$ \\
\hline $\mathrm{M}^{\mathrm{I}}-\mathrm{O} 4$ & $2.375(9)$ & $2.232(9)$ & $2.339(4)$ & $2.235(5)$ & $2.330(4)$ & $2.220(5)$ & $2.312(6)$ & $2.236(9)$ \\
\hline $\mathrm{Z}^{\mathrm{II}}-\mathrm{N} 1$ & $2.126(8)$ & $2.028(4)$ & $2.116(4)$ & $2.100(3)$ & $2.059(3)$ & $2.052(2)$ & $2.057(5)$ & $2.060(4)$ \\
\hline $\mathrm{Z}^{\mathrm{II}}-\mathrm{N} 2$ & $2.141(8)$ & $2.034(4)$ & $2.125(3)$ & $2.101(3)$ & $2.063(3)$ & $2.059(2)$ & $2.064(5)$ & $2.062(4)$ \\
\hline $\mathrm{Z}^{\mathrm{II}}-\mathrm{N}_{\mathrm{av}}$ & $2.133(6)$ & $2.031(2)$ & $2.121(4)$ & $2.100(4)$ & $2.061(2)$ & $2.055(3)$ & $2.061(3)$ & $2.061(1)$ \\
\hline$\Delta / \Lambda$ form & $\Lambda$ & $\Delta$ & $\Delta$ & $\Lambda$ & $\Lambda$ & $\Lambda$ & $\Delta$ & $\Lambda$ \\
\hline $2 \sigma^{2}$ & 68.0 & 37.3 & 60.9 & 56.2 & 49.1 & 48.5 & 53.9 & 53.5 \\
\hline${ }^{3} \lambda$ & $1.2 \times 10^{-5}$ & $2.2 \times 10^{-6}$ & $4.5 \times 10^{-6}$ & $5.0 \times 10^{-8}$ & $9.4 \times 10^{-7}$ & $2.9 \times 10^{-6}$ & $2.8 \times 10^{-6}$ & $2.3 \times \cdot 10^{-7}$ \\
\hline \multicolumn{9}{|c|}{ Bond length and distortion parameters of $\left[\mathrm{Z}^{\mathrm{II}}(\mathrm{bpy})_{3}\right]^{2+}$ cation in salts ${ }^{1}$} \\
\hline Complex & \multicolumn{2}{|c|}{$\left[\mathrm{Zn}(\mathrm{bpy})_{3}\right]^{2+}$} & {$\left[\mathrm{Cu}(\mathrm{bpy})_{3}\right]^{2+}$} & \multicolumn{2}{|c|}{$\left[\mathrm{Ru}(\mathrm{bpy})_{3}\right]^{2+}$} & \multicolumn{3}{|c|}{$\left[\mathrm{Os}(\mathrm{bpy})_{3}\right]^{2+}$} \\
\hline $\mathrm{Z}^{\mathrm{II}}-\mathrm{N}_{\text {rang. }}$ & \multicolumn{2}{|c|}{$2.110(5)-2.240(3)$} & $2.020(2)-2.454(2)$ & \multicolumn{2}{|c|}{$2.056(1)-2.060(1)$} & \multicolumn{3}{|c|}{$2.062(1)-2.062(1)$} \\
\hline $\mathrm{Z}^{\mathrm{II}}-\mathrm{N}_{\mathrm{av}}$ & \multicolumn{2}{|c|}{$2.159(10)$} & $2.136(11)$ & \multicolumn{2}{|c|}{$2.058(2)$} & \multicolumn{3}{|c|}{2.062} \\
\hline $2 \sigma^{2}$ & \multirow{2}{*}{\multicolumn{2}{|c|}{$\begin{array}{c}95.6 \\
4.8 \times 10^{-4}\end{array}$}} & 85.1 & \multicolumn{2}{|c|}{57.6} & \multicolumn{3}{|c|}{63.9} \\
\hline${ }^{3} \lambda$ & & & $5.7 \times 10^{-3}$ & \multicolumn{2}{|c|}{$6.8 \times 10^{-7}$} & \multicolumn{3}{|c|}{$3.7 \times 10^{-6}$} \\
\hline \multicolumn{9}{|c|}{$\begin{array}{l}{ }_{1} \text { The } \mathrm{M}^{\mathrm{II}}-\mathrm{N} \text { bonds lengths for }\left[\mathrm{Zn}(\mathrm{bpy})_{3}\right]\left(\mathrm{ClO}_{4}\right)_{2}[86],\left[\mathrm{Cu}(\mathrm{bpy})_{3}\right]\left(\mathrm{ClO}_{4}\right)_{2}[87],\left[\mathrm{Ru}(\mathrm{bpy})_{3}\right]\left(\mathrm{ClO}_{4}\right)_{2}[88] \text { and } \\
{\left[\mathrm{Os}(\mathrm{bpy})_{3}\right]\left(\mathrm{PF}_{6}\right)_{2}[89] \text { salts were taken from the published crystallographic data. }{ }^{2} \text { The bond angle variance: }} \\
\sigma^{2}=\frac{1}{11} \sum_{\mathrm{n}=1,12}\left(\theta_{\mathrm{n}}-90^{\circ}\right)^{2} \text {, where } \theta_{\mathrm{n}} \text { is one of the twelve } \mathrm{N}-\mathrm{Z}^{\mathrm{II}}-\mathrm{N} \text { angles in the coordination sphere [90]. }\end{array}$} \\
\hline \multicolumn{4}{|c|}{${ }^{3}$ The mean quadratic elongation: $\lambda=\frac{1}{6} \sum_{n=1,6}$} & \multicolumn{2}{|c|}{$\left[\frac{\left(d_{n}-\langle d\rangle\right)}{\langle d\rangle}\right]^{2}$, where $<d$} & nd $d_{\mathrm{n}}$ are th & e mean $Z^{\mathrm{II}}-\mathrm{N}$ & bond \\
\hline
\end{tabular}

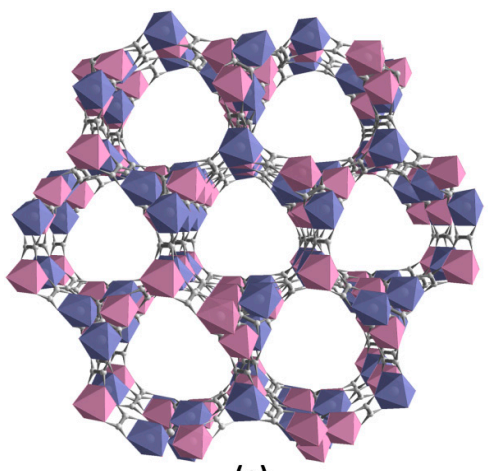

(a)

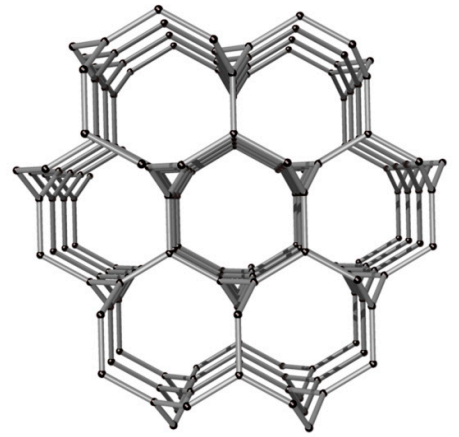

(b)

Figure 2. The $3 \mathrm{D}$ three-connected decagon anionic network $\left\{\left[\mathrm{M}^{\mathrm{I}} \mathrm{Ru}\left(\mathrm{C}_{2} \mathrm{O}_{4}\right)_{3}\right]^{2-}\right\}_{n}\left(\mathrm{M}^{\mathrm{I}}=\mathrm{Na}\right.$, Li): (a) view of honeycombed channels along the [111] direction and (b) its simplified topological representation, where black spheres represent a node of equivalent $\mathrm{Ru}^{\mathrm{III}}$ and $\mathrm{M}^{\mathrm{I}}$ centers. 
In fact, the $\left\{\left[\mathrm{M}^{\mathrm{I}} \mathrm{Ru}\left(\mathrm{C}_{2} \mathrm{O}_{4}\right)_{3}\right]^{2-}\right\}_{\mathrm{n}}\left(\mathrm{M}^{\mathrm{I}}=\mathrm{Na}^{+}, \mathrm{Li}^{+}\right)$anionic frameworks are cage-like structures with three-fold cavities formed as a result of helical substructure interconnection. The tris-chelating cationic $\left[\mathrm{Z}^{\mathrm{II}}(\mathrm{bpy})_{3}\right]^{2+}$ (where $\mathrm{Z}^{\mathrm{II}}=\mathrm{Zn}^{2+}, \mathrm{Cu}^{2+}, \mathrm{Ru}^{2+}, \mathrm{Os}^{2+}$; bpy $=2,2^{\prime}$-bipyridine) complex acting as the charge balanced template fits the large anionic cavities in a specific and highly symmetrical manner (Figure 3a). Interestingly, the cationic entity acts as a structural (appropriate size/shape), stoichiometric and chiral template, which repeats the homochiral conformational characteristics $(\Delta$ or $\Lambda$ ), such as SBUs in the polymeric network, resumed in Table 1 . The role of bulky $\left[Z^{\mathrm{II}}(\mathrm{bpy})_{3}\right]^{2+}$ cations in oxalate-based anionic coordination arrays has been previously investigated and has a significant effect on the network structure formation [72,92].

For the sake of topological simplification of the 3D framework structures, the anionic cavities are generalized as the self-dual natural tile characteristic for 10,3-net topologies and can be described as a triangle vertex figure with 14 vertices and three faces (Figure 3b). As illustrated in Figure 3c, the $\left[10^{3}\right]$ tiles sharing one face reconstruct porous spaces of the anionic network to form the $3 \mathrm{D}$ honeycombed architecture.

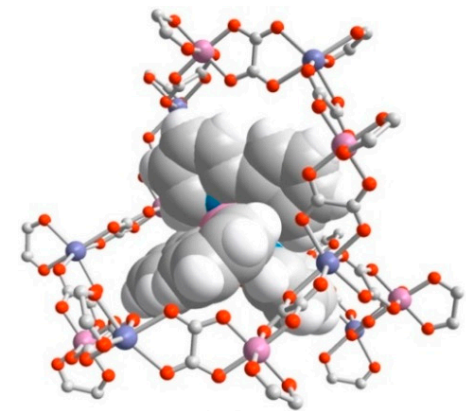

(a)

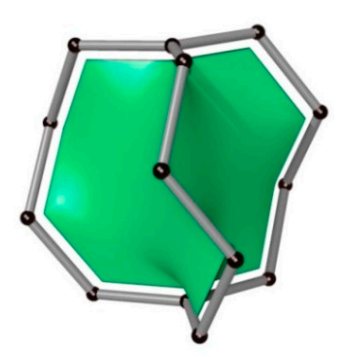

(b)

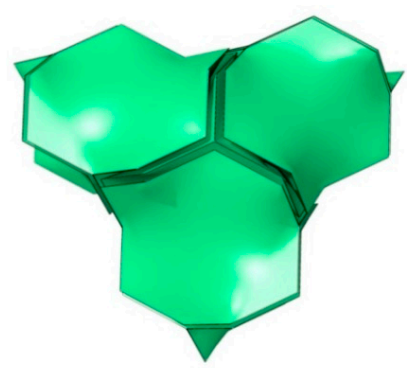

(c)

Figure 3. (a) Perspective view of the $\left[\mathrm{Z}^{\mathrm{II}}(\mathrm{bpy})_{3}\right]^{2+}\left(\mathrm{Z}^{\mathrm{II}}=\mathrm{Zn}^{2+}, \mathrm{Cu}^{2+}, \mathrm{Ru}^{2+}, \mathrm{Os}^{2+}\right)$ complex hosted in the anionic three-fold cage. (b) Simplified topological representation of the anionic cage (black nodes are $\mathrm{Ru}^{\mathrm{III}}$ and $\mathrm{M}^{\mathrm{I}}$ metal centers; grey rods are the oxalate ligand) with the srs triangular tile. (c) Tile packing, which reconstructs the cage structure in the 3D honeycomb-like framework.

Applying the models of Voronoi-Dirichlet polyhedra [93], an accessible volume of three-fold anionic cages in $\left\{\left[\mathrm{M}^{\mathrm{I}} \mathrm{Ru}\left(\mathrm{C}_{2} \mathrm{O}_{4}\right)_{3}\right]^{2-}\right\}_{\mathrm{n}}\left(\mathrm{M}^{\mathrm{I}}=\mathrm{Na}^{+}, \mathrm{Li}^{+}\right)$nets, the volume of cation $\left[\mathrm{Z}^{\mathrm{II}}(\mathrm{bpy})_{3}\right]^{2+}$ $\left(\mathrm{Z}^{\mathrm{II}}=\mathrm{Zn}^{2+}, \mathrm{Cu}^{2+}, \mathrm{Ru}^{2+}\right.$ and $\left.\mathrm{Os}^{2+}\right)$ incorporated in the networks and their volume in free salts were calculated and summarized in Figure 4. The volume of anionic cages in the $\left\{\left[\mathrm{NaRu}\left(\mathrm{C}_{2} \mathrm{O}_{4}\right)_{3}\right]^{2-}\right\}_{\mathrm{n}}$ framework are slightly bigger than those in the $\left\{\left[\mathrm{LiRu}\left(\mathrm{C}_{2} \mathrm{O}_{4}\right)_{3}\right]^{2-}\right\}_{n}$, which is caused by the difference between the ionic radii of $\mathrm{Na}$ and $\mathrm{Li}$ metal centers incorporated in the framework. Notably, the cationic template $\left[\mathrm{Z}^{\mathrm{II}}(\mathrm{bpy})_{3}\right]^{2+}\left(\right.$ where $\mathrm{Z}^{\mathrm{II}}=\mathrm{Zn}^{2+}, \mathrm{Cu}^{2+}, \mathrm{Ru}^{2+}, \mathrm{Os}^{2+}$ ) selectively residing in the anionic cages of 1, 3-8 undergoes a $6.9 \%-14.4 \%$ expansion compared to the corresponding cationic complex in the free salt forms.

Compound $\mathbf{2}$ is an outstanding case of this family, where the volume of the $\left[\mathrm{Zn}(\mathrm{bpy})_{3}\right]^{2+}$ template is smaller $(2.6 \%)$ than in the free salt, in contrast to $1,3-8$. Such a difference is related to the incorporation of additional water molecules (one per unit formula: $\left\{\left[\mathrm{Zn}^{\mathrm{II}}(\mathrm{bpy})_{3}\right]\left(\mathrm{H}_{2} \mathrm{O}\right)\left[\mathrm{LiCr}\left(\mathrm{C}_{2} \mathrm{O}_{4}\right)_{3}\right]\right\}_{\mathrm{n}}$ ) and was observed in analogous compounds $\left\{\left[\mathrm{Z}^{\mathrm{II}}(\mathrm{bpy})_{3}\right]\left(\mathrm{H}_{2} \mathrm{O}\right)\left[\mathrm{LiCr}\left(\mathrm{C}_{2} \mathrm{O}_{4}\right)_{3}\right]\right\}_{\mathrm{n}}\left(\mathrm{Z}^{\mathrm{II}}=\mathrm{Ni}^{2+}, \mathrm{Ru}^{2+}\right)[71]$ and $\left\{\left[\mathrm{Z}^{\mathrm{III}}(\mathrm{bpy})_{3}\right](\mathrm{X})\left[\mathrm{NaM}^{\mathrm{III}}\left(\mathrm{C}_{2} \mathrm{O}_{4}\right)_{3}\right]\right\}_{\mathrm{n}}\left(\mathrm{M}^{\mathrm{III}}=\mathrm{Cr}^{3+}, \mathrm{Al}^{3+}, \mathrm{Rh}^{3+} ; \mathrm{Z}^{\mathrm{III}}=\mathrm{Cr}^{3+}, \mathrm{Rh}^{3+}, \mathrm{Co}^{3+} ; \mathrm{X}=\mathrm{ClO}_{4}{ }^{-}\right.$, $\mathrm{PF}_{6}{ }^{-}$) [72-76], The special packing arrangement of $\left[\mathrm{Z}^{\mathrm{III}}(\mathrm{bpy})_{3}\right]^{3+}$ or $\left[\mathrm{Z}^{\mathrm{II}}(\mathrm{bpy})_{3}\right]^{2+}$ cations creates cubic-shaped cavities able to encapsulate small anions $\left(\mathrm{ClO}_{4}{ }^{-}\right.$or $\left.\mathrm{PF}_{6}{ }^{-}\right)$or neutral molecules $\left(\mathrm{H}_{2} \mathrm{O}\right)$. In the case of 2, three pairs of parallel aligned, adjacent bpy ligands, perpendicularly oriented to each other, form the cubic-shaped vacancies in which the water molecules reside with full occupancy of this site. 


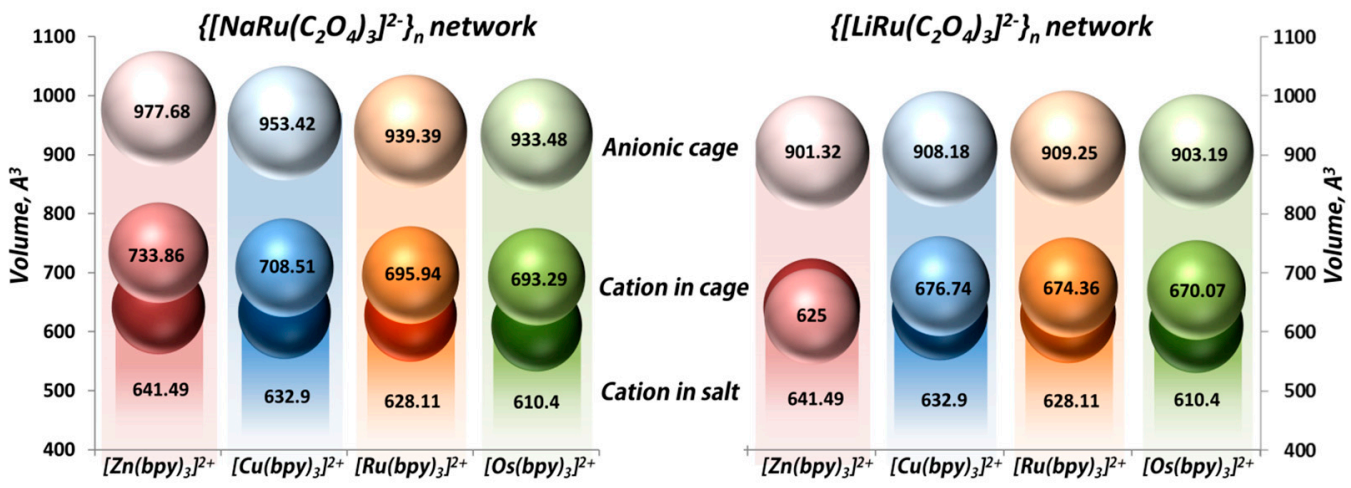

Figure 4. Representation of accessible volumes of anionic cages in $\left\{\left[\mathrm{NaRu}\left(\mathrm{C}_{2} \mathrm{O}_{4}\right)_{3}\right]^{2-}\right\}_{\mathrm{n}}$ (right) and networks $\left\{\left[\mathrm{LiRu}\left(\mathrm{C}_{2} \mathrm{O}_{4}\right)_{3}\right]^{2-}\right\}_{\mathrm{n}}(\mathrm{left})$, the volumes of $\left[\mathrm{Z}^{\mathrm{II}}(\mathrm{bpy})_{3}\right]^{2+}\left(\mathrm{Z}^{\mathrm{II}}=\mathrm{Zn}^{2+}, \mathrm{Cu}^{2+}, \mathrm{Ru}^{2+}, \mathrm{Os}^{2+}\right)$ cationic complexes in their salt forms (darker spheres) and incorporated in corresponding $3 \mathrm{D}$ polymeric nets (medium spheres). The volume calculation for the $\left[\mathrm{Z}^{\mathrm{II}}(\mathrm{bpy})_{3}\right]^{2+}$ complex in salt forms has been performed using the published crystallographic data [86-89].

However, in the actual case of the structure of 2, the capture of water molecules into these cavities is expected, taking into account the aqueous preparation of the compound. Figure 5 shows the packing arrangement of three adjacent tris-chelated $\left[\mathrm{Zn}^{\mathrm{II}}(\mathrm{bpy})_{3}\right]^{2+}$ cations exhibiting the cubic-shaped cavity, which is drawn with the frontal bpy ligand, partially omitted in order to have a free view into the cage where the $\mathrm{H}_{2} \mathrm{O}$ molecule is entrapped. The volume of this cubic cage in Compound 2 is about $45 \AA^{3}$ (Figure S8). Consequently, the size decreasing of the $\left[\mathrm{Zn}^{\mathrm{II}}(\mathrm{bpy})_{3}\right]^{2+}$ cationic template observed in 2 can be explained as a result of a steric pressure effect introduced by incorporation of additional water molecules into the cubic-shaped cavities.
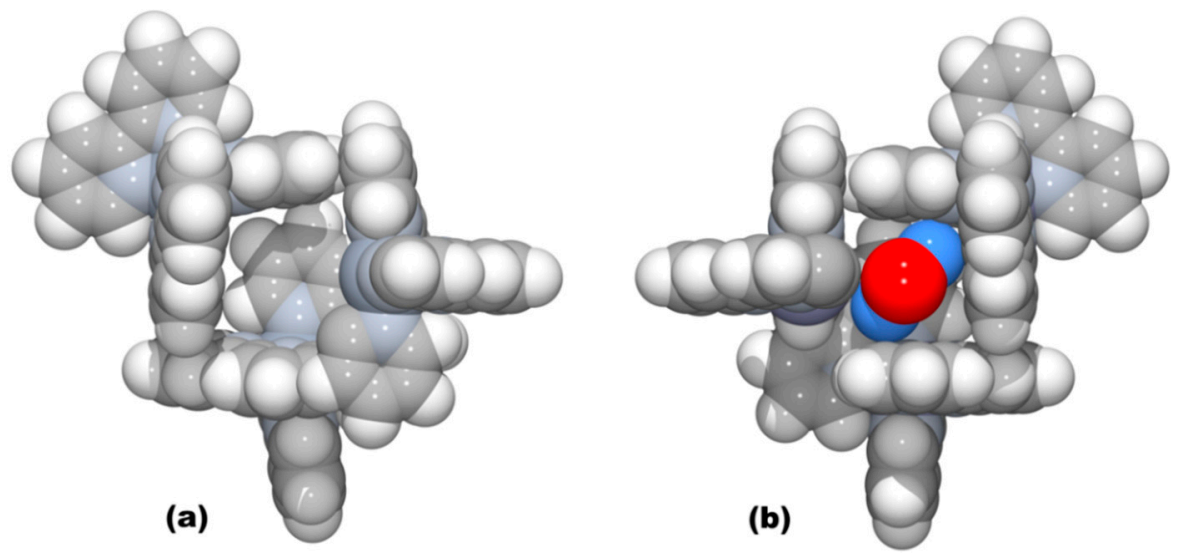

Figure 5. Space filling representation of cubic-shaped cages formed by three pairs of parallel-oriented bipyridine ligands proceeding from three adjacent $\left[\mathrm{Zn}^{\mathrm{II}}(\mathrm{bpy})_{3}\right]^{2+}$ template cations: (a) view of the empty space of the cubic cage in Compound 1; (b) view of the cubic cage in Compound 2 where the water molecule is located. Part of the bipyridine ligand located at the top of the cage is omitted for clarity.

\subsection{Infrared Spectroscopy}

The IR spectra of 1-8 are very similar (Figure S9), showing the characteristic absorption bands of the oxalate ligand in the regions $1610-1625 \mathrm{~cm}^{-1}\left(v_{\text {asO }}-C-O\right), 1305-1315 \mathrm{~cm}^{-1}, 1350-1365 \mathrm{~cm}^{-1}$ $\left(v_{S O-C-O}\right)$ and $795-805 \mathrm{~cm}^{-1}\left(\delta_{O-C-O}\right)$. The bands between 540 and $490 \mathrm{~cm}^{-1}$ are assigned to the $\mathrm{Ru}-\mathrm{O}, \mathrm{Li} / \mathrm{Na}-\mathrm{O}$ and $\mathrm{M}^{\mathrm{II}}-\mathrm{N}$ stretching vibrations. The bands between 3100 and $2800 \mathrm{~cm}^{-1}$ and $1675-1400 \mathrm{~cm}^{-1}$ are attributed to the $\mathrm{C}-\mathrm{H}, \mathrm{C}_{\mathrm{ar}}-\mathrm{C}_{\mathrm{ar}}$ and $\mathrm{C}_{\mathrm{ar}}=\mathrm{N}$ stretching frequencies of the aromatic 
group. The series of bands at $1250-1000 \mathrm{~cm}^{-1}$ and near $3030-3050 \mathrm{~cm}^{-1}$ correspond to the aromatic $=\mathrm{C}-\mathrm{H}$ stretching vibration.

\subsection{Thermogravimetric Analysis}

The thermal stability of $\mathbf{1 - 8}$ in air and nitrogen atmospheres was investigated. The thermogravimetric curves (TG and derivative TG), SDTA and mass spectrometry analysis of evacuated vapors for 1-8 in both air and nitrogen atmospheres are depicted in Figures S10-S11 and S13-S14 (Supplementary Materials), respectively. As represented, the thermogravimetric analysis results demonstrate similar decomposition behaviors, confirming the isomorphic nature of Compounds 1-8. The degradation processes occurred in one single step simultaneously in both air and nitrogen atmospheres and very closely resemble each other. As summarized in Table S2 (Supplementary Materials), in air atmosphere, degradation of 1-8 proceeds through one continuous stage in which a mass loss of $63.6 \%-75.2 \%$ (depending on the compositional characteristics) is observed in the range $180-600{ }^{\circ} \mathrm{C}$. This mass loss is associated with a broad exothermic peak on the SDTA and DSC curves (Figures S10-S12, Supplementary Materials) and corresponds to simultaneous decomposition of the organic template and ligand. The associated mass spectrometry $\mathrm{m} / \mathrm{z} 18,44$ and 46 curves are in good agreement with the TG/dTG curves and occur as one broad maximum coinciding with the maximum of mass loss in dTG curves, suggesting continuous structure collapsing and oxidational degradation of the ligands.

Oppositely, in nitrogen atmosphere, the pyrolysis of Compounds 1-8 proceeds in three steps (Table S3, Supplementary Materials). As represented in Figures S13 and S14 (Supplementary Materials), these decomposition steps exhibit endothermic effects on the SDTA (Figures S13-S14, Supplementary Materials) and DSC curves (Figure S15; see the Supplementary Materials), which are associated with mass spectrometry $\mathrm{m} / \mathrm{z} 15,18$ and 44 peaks, indicating stepwise decomposition of the polymeric architectures. Notably, the observed mass losses in nitrogen atmosphere do not correspond to those calculated theoretically (Table S3, Supplementary Materials). The found inconsistency between expected and theoretical mass losses can be attributed to the formation of carbon solid residues, which are the main product formed in the pyrolysis processes. Additionally, a composition of the residual solids of 1-8 after decomposition in air or nitrogen atmospheres was identified applying the powder $\mathrm{X}$-ray diffraction technique. As a result, the residue powders formed after decomposition in air atmosphere consist of a mixture of $\mathrm{RuO}_{2}, \mathrm{Li}_{2} \mathrm{O}$ (for Compounds 2, 4, 6, 8) or $\mathrm{Na}_{2} \mathrm{O}$ (Compounds $1,3,5,7)$ and $\mathrm{M}^{\mathrm{II}} \mathrm{O}\left(\mathrm{M}^{\mathrm{II}}=\mathrm{Zn}(\mathbf{1}, 2), \mathrm{Cu}(3,4)\right)$ or $\mathrm{M}^{\mathrm{IV}} \mathrm{O}_{2}\left(\mathrm{M}^{\mathrm{IV}}=\mathrm{Ru}(5,6)\right.$, Os $\left.(7,8)\right)$, while in nitrogen atmosphere, the residual composition has been identified as a mixture of Ru metal, $\mathrm{Li}_{2} \mathrm{O}$ (for Compounds 2, 4, 6, 8) or $\mathrm{Na}_{2} \mathrm{O}$ (Compounds 1, 3, 5, 7), $\mathrm{M}^{\mathrm{II}} \mathrm{O}\left(\mathrm{M}^{\mathrm{II}}=\mathrm{Zn}(1,2), \mathrm{Cu}(3,4)\right)$ or metallic osmium $(7,8)$.

\subsection{UV-Vis Spectroscopy}

The room-temperature UV-Vis-NIR diffuse reflectance spectra of the powder samples corresponding to 1-8 are represented in Figure 6. All spectra consist of three groups of bands: the high energy bands observed between 200 and $330 \mathrm{~nm}$ are assigned to the $\pi \rightarrow \pi^{*}$ transition of bpy ligands; the intense broad band at $c a .400 \mathrm{~nm}$ corresponds to the MLCT transition in $\left[\mathrm{Na} / \mathrm{LiRu}\left(\mathrm{C}_{2} \mathrm{O}_{4}\right)_{3}\right]^{2-}$ units; whereas the weaker bands in the VIS-NIR region have been assigned to ligand-field transitions within the $\left[\mathrm{Z}^{\mathrm{II}}(\mathrm{bpy})_{3}\right]^{2+}$ cationic templates of Compounds 1-8.

Figure 6a shows a comparison of the diffuse-reflectance spectra of $\mathbf{1}, \mathbf{2}$ and $\left[\mathrm{Zn}(\mathrm{bpy})_{3}\right]\left(\mathrm{ClO}_{4}\right)_{2}$ compounds. As expected, the spectrum of the $\left[\mathrm{Zn}(\mathrm{bpy})_{3}\right]^{2+}$ complex does not appear to have $d-d$ transitions due to the close shell electronic configuration $\left(\mathrm{t}_{2 \mathrm{~g}}{ }^{6} \mathrm{eg}_{\mathrm{g}}^{4}\right)$ for the $d^{10} \mathrm{Zn}^{2+}$ ion [68]. However, the spectra of 1 and 2 exhibit a broad adsorption band $c a .700 \mathrm{~nm}$, which was assigned to the $d-d$ $\left(\mathrm{Ru}^{3+}\right)$ spin-forbidden ${ }^{2} \mathrm{~T}_{2} \rightarrow{ }^{4} \mathrm{~T}_{2}$ transition within the $\left[\mathrm{Na} / \mathrm{LiRu}\left(\mathrm{C}_{2} \mathrm{O}_{4}\right)_{3}\right]^{2-}$ framework units [94]. The Vis-NIR spectral region of 3 and 4 coordination polymers templated by the $\left[\mathrm{Cu}(\mathrm{bpy})_{3}\right]^{2+}$ cationic complex (Figure 6b) reveal the adsorption band of $c a .690 \mathrm{~nm}$ that was assigned to the ${ }^{2} \mathrm{E}_{\mathrm{g}} \rightarrow^{2} \mathrm{~T}_{2 \mathrm{~g}}$ single 
electron transition, which is expected in the octahedral crystal field for the $\mathrm{Cu}^{2+}$ ion $\left({ }^{2} \mathrm{~T}_{2 \mathrm{~g}}\right)$ with the $\mathrm{t}_{2 \mathrm{~g}}{ }^{5} \mathrm{eg}^{4}$ excited electronic state [95].
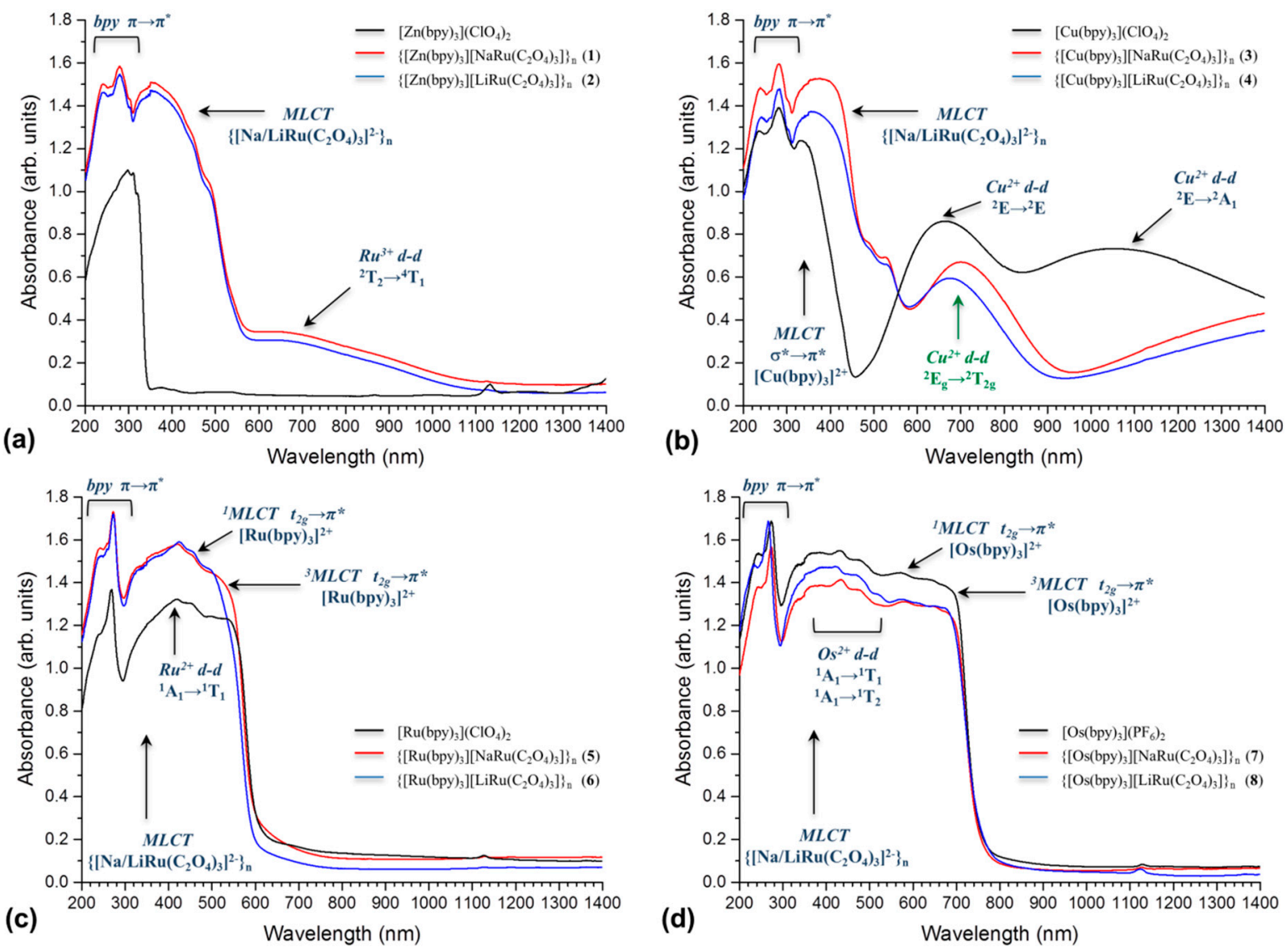

Figure 6. Comparison of room temperature UV-Vis-NIR diffuse-reflectance spectrum for: $\quad$ (a) $\quad\left\{\left[\mathrm{Zn}^{\mathrm{II}}(\mathrm{bpy})_{3}\right]\left[\mathrm{NaRu}\left(\mathrm{C}_{2} \mathrm{O}_{4}\right)_{3}\right]\right\}_{\mathrm{n}} \quad$ (1), $\quad\left\{\left[\mathrm{Zn}^{\mathrm{II}}(\mathrm{bpy})_{3}\right]\left(\mathrm{H}_{2} \mathrm{O}\right)\left[\mathrm{LiRu}\left(\mathrm{C}_{2} \mathrm{O}_{4}\right)_{3}\right]\right\}_{\mathrm{n}} \quad$ (2) and $\left[\mathrm{Zn}(\mathrm{bpy})_{3}\right]\left(\mathrm{ClO}_{4}\right)_{2} ; \quad$ (b) $\left\{\left[\mathrm{Cu}^{\mathrm{II}}(\mathrm{bpy})_{3}\right]\left[\mathrm{M}^{\mathrm{I}} \mathrm{Ru}\left(\mathrm{C}_{2} \mathrm{O}_{4}\right)_{3}\right]\right\}_{\mathrm{n}}$ and $\left[\mathrm{Cu}^{\mathrm{II}}(\mathrm{bpy})_{3}\right]\left(\mathrm{ClO}_{4}\right)_{2} \quad\left(\mathrm{M}^{\mathrm{I}}=\mathrm{Na}\right.$ (3), $\mathrm{Li}$ (4)); (c) $\left\{\left[\mathrm{Ru}^{\mathrm{II}}(\mathrm{bpy})_{3}\right]\left[\mathrm{M}^{\mathrm{I}} \mathrm{Ru}\left(\mathrm{C}_{2} \mathrm{O}_{4}\right)_{3}\right]\right\}_{\mathrm{n}}$ and $\left[\mathrm{Ru}(\mathrm{bpy})_{3}\right]\left(\mathrm{ClO}_{4}\right)_{2} \quad\left(\mathrm{M}^{\mathrm{I}}=\mathrm{Na}\right.$ (5), $\mathrm{Li}$ (6)); (d) $\left\{\left[\mathrm{Os}^{\mathrm{II}}(\mathrm{bpy})_{3}\right]\left[\mathrm{M}^{\mathrm{I}} \mathrm{Ru}\left(\mathrm{C}_{2} \mathrm{O}_{4}\right)_{3}\right]\right\}_{\mathrm{n}}$ and $\left[\mathrm{Os}(\mathrm{bpy})_{3}\right]\left(\mathrm{PF}_{6}\right)_{2}\left(\mathrm{M}^{\mathrm{I}}=\mathrm{Na}(7), \mathrm{Li}(8)\right)$.

Normally, the octahedral coordination of $\mathrm{Cu}^{2+}$ ions undergoes Jahn-Teller distortion, leading to the trigonally-distorted pseudo- $D_{3}$ symmetry and can be observed in the corresponding spectrum of the $\left[\mathrm{Cu}(\mathrm{bpy})_{3}\right]\left(\mathrm{ClO}_{4}\right)_{2}$ compound (Figure $6 \mathrm{~b}$ ), where $d-d$ transitions appeared as a medium-strong band of $c a .680 \mathrm{~nm}$, and a sharp band of $c a .1100 \mathrm{~nm}$ should be treated as the trigonal field and assigned to ${ }^{2} \mathrm{E} \rightarrow{ }^{2} \mathrm{E}$ and ${ }^{2} \mathrm{E} \rightarrow{ }^{2} \mathrm{~A}_{1}$ transitions, respectively [96]. Based on these observations, the fact that the $\left\{\left[\mathrm{M}^{\mathrm{I}} \mathrm{Ru}\left(\mathrm{C}_{2} \mathrm{O}_{4}\right)_{3}\right]^{2-}\right\}_{\mathrm{n}}\left(\mathrm{M}^{\mathrm{I}}=\mathrm{Na}^{+}, \mathrm{Li}^{+}\right)$anionic framework rigidly restricts Jahn-Teller distortion in the guest $\left[\mathrm{Cu}(\mathrm{bpy})_{3}\right]^{2+}$ cationic complex is concluded. Furthermore, the corresponding structural distortion parameters (bond angle variance $\left(\sigma^{2}\right)$ and mean quadratic elongation $(\lambda)$ ) calculated for the $\left[\mathrm{Cu}(\mathrm{bpy})_{3}\right]^{2+}$ complex in 3 and 4 frameworks, which are summarized in Table 1 , suggest that the coordination environment of the $\mathrm{Cu}^{2+}$ ion in the template cationic complex exhibits more regularized octahedral geometry than that found for the corresponding free salt form.

The diffuse-reflectance spectra of Compounds $\mathbf{5}$ and $\mathbf{6}$ are similar with respect to the corresponding $\left[\mathrm{Ru}(\mathrm{bpy})_{3}\right]\left(\mathrm{ClO}_{4}\right)_{2}$ complex, and the Vis-NIR region consists of several high intensity bands (Figure $6 \mathrm{c}$ ), which are attributed to electron transitions within the low-spin $\left[\mathrm{Ru}(\mathrm{bpy})_{3}\right]^{2+}$ complex, where the $\mathrm{Ru}^{2+}$ ion possesses the $\mathrm{t}_{2 \mathrm{~g}}{ }^{5} \mathrm{e}_{\mathrm{g}}{ }^{1}$ electronic configuration [95]. Thus, the absorption band of $c a .450 \mathrm{~nm}$ is assigned to the ${ }^{1} \mathrm{~A}_{1} \rightarrow^{1} \mathrm{~T}_{1}$ transition. Moreover, the shoulder centered at $480 \mathrm{~nm}$ corresponds to the $t_{2 \mathrm{~g}} \rightarrow \pi^{*}$ metal-ligand charge transfer $\left({ }^{1} \mathrm{MLCT}\right)$ transition, while the broad shoulder observed at 
$560 \mathrm{~nm}$ belongs to a spin-forbidden third $t_{2 \mathrm{~g}} \rightarrow \pi^{*}$ metal-ligand charge transfer ( $\left.{ }^{3} \mathrm{MLCT}\right)$ transition [97]. Similarly, Compounds 7 and 8 exhibit diffuse-reflectance spectra close to the $\left[\mathrm{Os}(\mathrm{bpy})_{3}\right]\left(\mathrm{PF}_{6}\right)_{2}$ complex. As shown in Figure $6 \mathrm{~d}$, the Vis-NIR region of spectra consists of several overlapped bands located from 410-520 nm and was assigned to the ${ }^{1} \mathrm{~A}_{1} \rightarrow{ }^{1} \mathrm{~T}_{2}$ and ${ }^{1} \mathrm{~A}_{1} \rightarrow{ }^{1} \mathrm{~T}_{1} d-d$ transitions, which are expected for the low-spin $\left[\mathrm{Os}(\mathrm{bpy})_{3}\right]^{2+}$ complex with the $\mathrm{Os}^{2+}$ ion in the $\mathrm{t}_{2 \mathrm{~g}}{ }^{5} \mathrm{eg}_{\mathrm{g}}{ }^{1}$ ground state [95]. Similarly to $\left[\mathrm{Ru}(\mathrm{bpy})_{3}\right]^{2+}$-contained compounds, the diffuse-reflectance spectra of $\mathbf{7}$ and $\mathbf{8}$, as well as [Os $\left.(\mathrm{bpy})_{3}\right]\left(\mathrm{PF}_{6}\right)_{2}$ exhibit characteristic shoulders localized from $560800 \mathrm{~nm}$, which are attributed to the $t_{2 \mathrm{~g}} \rightarrow \pi^{*}$ metal-ligand charge transfer (MLCT) along with the spin-forbidden third $t_{2 \mathrm{~g}} \rightarrow \pi^{*}$ metal-ligand charge transfer $\left({ }^{3} \mathrm{MLCT}\right)$ transition [98].

The band gaps of 1-8 were estimated from Tauc plots [99] obtained from UV-Vis diffuse-reflectance data transformed by the Kubelka-Munk function (Figure S16). The band gaps $\left(E_{\mathrm{g}}\right)$ were determined extrapolating the intersection point between the baseline and the linear portion of the adsorption edge in a plot represented as function $(\alpha h v)^{3 / 2}$ against energy $(h v, \mathrm{eV})$. The optical adsorption related to $E_{\mathrm{g}}$ in the region of MLCT transition, which is assumed to be directly forbidden, can be assessed at $2.54 \mathrm{eV}$ for $1,2.31 \mathrm{eV}$ for $2,2.68 \mathrm{eV}$ for $3,2.67 \mathrm{eV}$ for $4,2.10 \mathrm{eV}$ for $5,2.11 \mathrm{eV}$ for 6, $1.68 \mathrm{eV}$ for 7 and $1.67 \mathrm{eV}$ for 8 , respectively. The determined values of band gaps for coordination polymers $1-8$ follow the order $3 \approx 4>1>2>5 \approx 6>7 \approx 8$.

The efficiency of photoinduced energy and electron migration processes occurring between the photosensitive component and the catalytically-active centers in MOFs/CPs upon light irradiation are essential goals in the rational design of photo-catalytically-active MOFs/CPs [100]. Thus, inspired by the early study of Kimura et al. [101], which demonstrated efficient intramolecular energy and electron transfer taking place in a homogeneous solution between $\left[\mathrm{Co}\left(\mathrm{C}_{2} \mathrm{O}_{4}\right)_{3}\right]^{3-}$ and $\left[\mathrm{Ru}(\mathrm{bpy})_{3}\right]^{2+}$ complexes, and supported by later works of Decurtins et al. $[62,63,69,70,74,76]$, which evidenced the existence of $h v$-assisted resonant energy migration between $\left[\mathrm{Cr}\left(\mathrm{C}_{2} \mathrm{O}_{4}\right)_{3}\right]^{3-}$ and $\left[\mathrm{M}^{\mathrm{II} / \mathrm{III}}(\mathrm{bpy})_{3}\right]^{2+/ 3+}$ components in $\left\{\left[\mathrm{Z}^{\mathrm{II} / \mathrm{III}}(\mathrm{bpy})_{3}\right]\left[\mathrm{NaCr}\left(\mathrm{C}_{2} \mathrm{O}_{4}\right)_{3}\right]\right\}_{\mathrm{n}}\left(\mathrm{Z}^{\mathrm{II}}=\mathrm{Ru}^{2+}, \mathrm{Zn}^{2+}, \mathrm{Os}^{2+}, \mathrm{Fe}^{2+} ; \mathrm{M}^{\mathrm{III}}=\mathrm{Rh}^{3+}, \mathrm{Cr}^{3+}\right)$ coordination networks, we envisioned that the coordination polymers 1-8 can act as self-supported photocatalysts.

\subsection{Photocatalytic Activity}

The photocatalytic splitting of water for hydrogen production using Compounds 1-8 under UV $(\leqslant 366 \mathrm{~nm})$ and VIS $(\geqslant 417 \mathrm{~nm})$ light irradiation was examined. In a typical experiment, the reactions were performed in a reactor equipped with a refrigerated 500-W Hg-lamp $(\leqslant 366 \mathrm{~nm})$ and using $10 \mu \mathrm{mol}$ of heterogeneous catalyst $\mathbf{1 - 8}$ dispersed in a water $\left(\mathrm{H}_{2} \mathrm{O}\right) /$ triethylamine (TEA) mixture $(v / v=1.4: 1)$, where TEA acts as the electron donor. The amounts of $\mathrm{H}_{2}$ produced over 1-8 photocatalysts under $8 \mathrm{~h}$ of UV light irradiation are depicted in Figure 7.

As seen in Figure 7 (left), the heterogeneous catalysts 1-8 are active in the photoreductive water splitting reaction, forming $1.26 \mu \mathrm{mol}$ (TON of 0.12 ) of $\mathrm{H}_{2}$ after $8 \mathrm{~h}$ under UV light irradiation. Catalysts 7 and 8 exhibit the highest photocatalytic performance, compared to the activity of the other compounds, and their activities decrease through the sequence $8>7>6>5>2>1 \approx 4>3$. Interestingly, this sequence of photocatalytic activity is directly opposed to the calculated band gaps for these compounds (Figure 7, right). Therefore, the synergistic effects of the smallest band gap and chemical nature of the $\left[\mathrm{Z}^{\mathrm{II}}(\mathrm{bpy})_{3}\right]^{2+}$ cationic template are the main factors determining the photocatalytic activities of 1-8 under UV light irradiation. Blank reactions were performed to ensure that $\mathrm{H}_{2}$ production was light-promoted and conducted over a heterogeneous catalyst. One blank was UV-illuminated without the catalyst, and another was in the dark with the catalyst under the same experimental conditions. No $\mathrm{H}_{2}$ was detected in the above two blank tests. A "hot filtration" test was conducted with 6 , in which the heterogeneous catalyst, previously exposed to $8 \mathrm{~h}$ of reaction under UV light, was removed by centrifugation, and the transparent uncolored reactant solution was returned into the photolysis cell (previously degassed and filled with Ar) for an additional consecutive photocatalytic run. As a result, no $\mathrm{H}_{2}$ was detected, which indicates that the detected photoactivities are promoted by heterogeneous catalysts rather than by leached soluble species. 


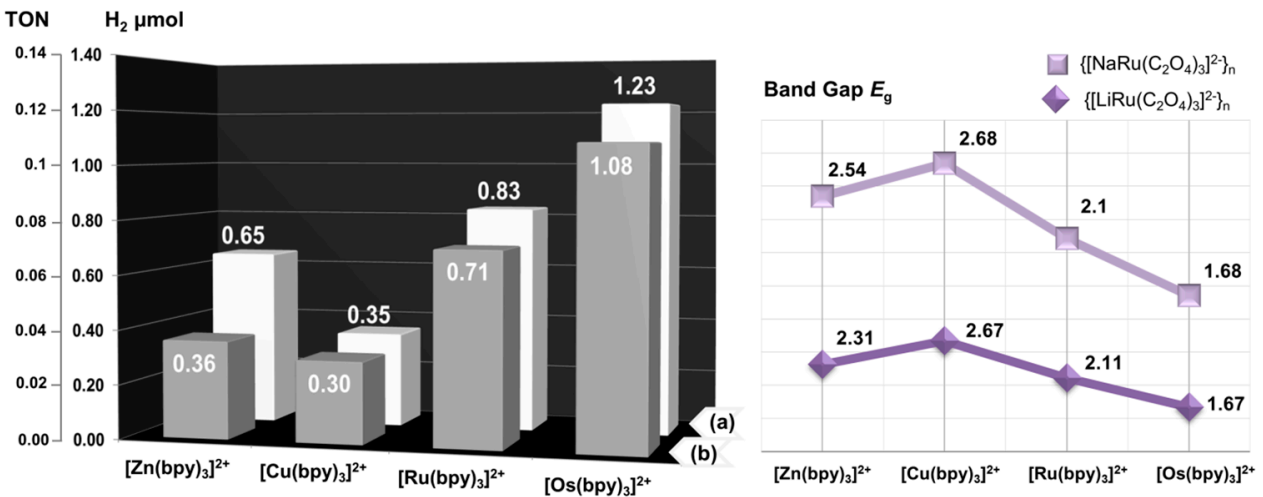

Figure 7. (Left) Amounts and TON values corresponding to $\mathrm{H}_{2}$ evolved during the reductive water splitting reaction using photocatalysts $1-8$, which contain $\left[\mathrm{Zn}(\mathrm{bpy})_{3}\right]^{2+},\left[\mathrm{Cu}(\mathrm{bpy})_{3}\right]^{2+},\left[\mathrm{Ru}(\mathrm{bpy})_{3}\right]^{2+}$ and $\left[\mathrm{Os}(\mathrm{bpy})_{3}\right]^{2+}$ complex cations incorporated in (a) $\left\{\left[\mathrm{LiRu}\left(\mathrm{C}_{2} \mathrm{O}_{4}\right)_{3}\right]^{2-}\right\}_{\mathrm{n}}$ and (b) $\left\{\left[\mathrm{NaRu}\left(\mathrm{C}_{2} \mathrm{O}_{4}\right)_{3}\right]^{2-}\right\}_{\mathrm{n}}$ networks under $8 \mathrm{~h}$ of UV ( $\leqslant 366 \mathrm{~nm}$ ) light irradiation. Photoreaction mixtures contained $10 \mu \mathrm{mol}$ of heterogeneous catalyst, $7 \mathrm{~mL}$ of TEA and $10 \mathrm{~mL}$ of $\mathrm{H}_{2} \mathrm{O}$. TON $=\mu \mathrm{mol}$ of $\mathrm{H}_{2}$ evolved $/ 10 \mu \mathrm{mol}$ of catalyst. (Right) The values of band gaps were determined by diffuse-reflectance measurements for Compounds 1-8.

Additionally, the photocatalytic activities of 1-8 were examined under VIS light irradiation under the same reaction conditions. As shown in Figure 8, all coordination compounds also catalyze the photoreduction of water to $\mathrm{H}_{2}$, albeit less efficiently. These differences in photocatalytic activities of 1-8 under UV and VIS irradiation can be explained in light of the distinct mechanisms of energy transfer taking place within the $\left\{\left[\mathrm{Z}^{\mathrm{II} / \mathrm{III}}(\mathrm{bpy})_{3}\right]\left[\mathrm{M}^{\mathrm{I}} \mathrm{M}^{\mathrm{III}}\left(\mathrm{C}_{2} \mathrm{O}_{4}\right)_{3}\right]\right\}_{n}$ host-guest system, which earlier was evidenced by Decurtins et al. for analogous $\left\{\left[\mathrm{Z}^{\mathrm{II} / \mathrm{III}}(\mathrm{bpy})_{3}\right]\left[\mathrm{NaCr}\left(\mathrm{C}_{2} \mathrm{O}_{4}\right)_{3}\right]\right\}_{\mathrm{n}}\left(\mathrm{Z}^{\mathrm{II}}=\mathrm{Ru}^{2+}, \mathrm{Zn}^{2+}, \mathrm{Os}^{2+}\right.$, $\left.\mathrm{Fe}^{2+} ; \mathrm{Z}^{\mathrm{III}}=\mathrm{Rh}^{3+}, \mathrm{Cr}^{3+}\right)$ compounds $[70,73,102]$.

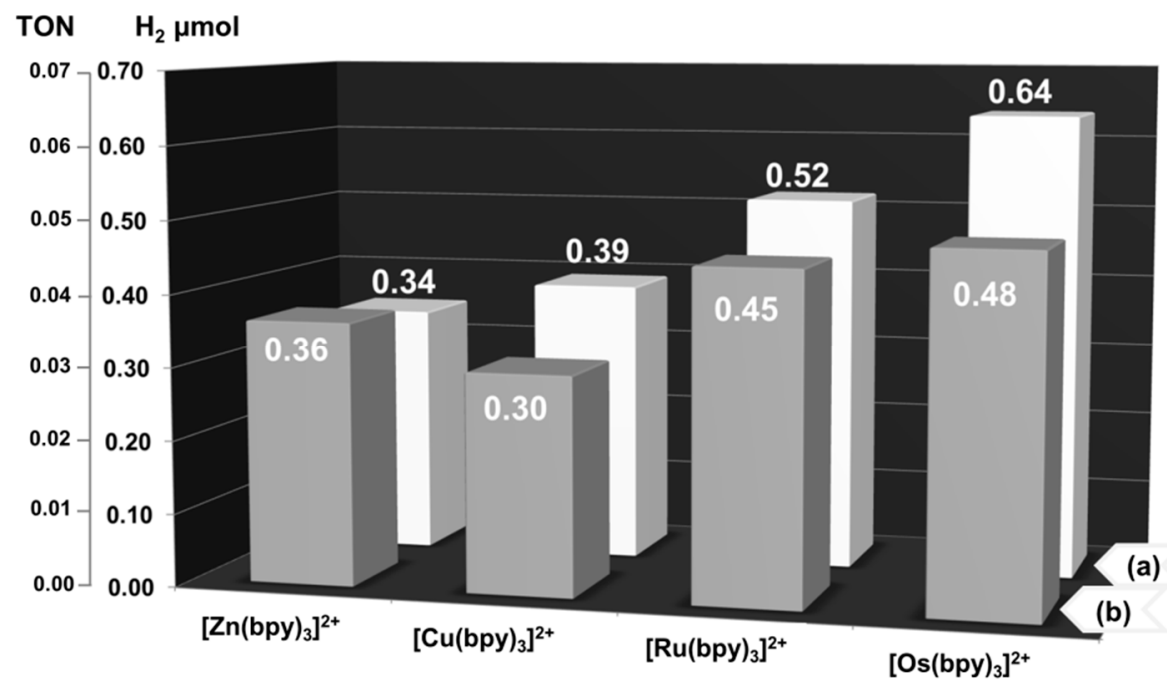

Figure 8. Amounts and TON values corresponding to $\mathrm{H}_{2}$ evolved during the reductive water splitting reaction using photocatalysts $1-8$, which contain $\left[\mathrm{Zn}(\mathrm{bpy})_{3}\right]^{2+},\left[\mathrm{Cu}(\mathrm{bpy})_{3}\right]^{2+},\left[\mathrm{Ru}(\mathrm{bpy})_{3}\right]^{2+}$ and $\left[\mathrm{Os}(\mathrm{bpy})_{3}\right]^{2+}$ complex cations incorporated in (a) $\left\{\left[\mathrm{LiRu}\left(\mathrm{C}_{2} \mathrm{O}_{4}\right)_{3}\right]^{2-}\right\}_{\mathrm{n}}$ and (b) $\left\{\left[\mathrm{NaRu}\left(\mathrm{C}_{2} \mathrm{O}_{4}\right)_{3}\right]^{2-}\right\}_{\mathrm{n}}$ networks under $8 \mathrm{~h}$ of Vis $(\geqslant 417 \mathrm{~nm}$ ) light irradiation (left). Photoreaction mixtures contained $10 \mu \mathrm{mol}$ of heterogeneous catalyst, $7 \mathrm{~mL}$ of TEA and $10 \mathrm{~mL}$ of $\mathrm{H}_{2} \mathrm{O}$. TON $=\mu \mathrm{mol}$ of $\mathrm{H}_{2}$ produced $/ 10 \mu \mathrm{mol}$ of catalyst. 
Table 2. Comparison of photocatalytic performances of known MOFs/CPs used in the photoreduction of water to $\mathrm{H}_{2}$ under UV and Vis light.

\begin{tabular}{|c|c|c|c|c|c|c|}
\hline MOF/CP & $\mathbf{H}_{2}(\mu \mathrm{mol})$ & $\mathrm{T}$ (h) & TON & $\begin{array}{c}\text { TOF } \\
\left(\text { TON }^{-h^{-1}}\right)\end{array}$ & $\lambda(\mathrm{nm})$ & Ref. \\
\hline$\left[\mathrm{Ru}^{\mathrm{II}, \mathrm{III}}{ }_{2}(p-\mathrm{BDC})_{2} \mathrm{BF}_{4}\right]_{\mathrm{n}}$ & 29.3 & 4 & $47.0^{1}$ & 11.7 & $>420$ & \multirow{3}{*}{$\begin{array}{l}{[47]} \\
{[48]}\end{array}$} \\
\hline$\left[\mathrm{Ru}^{\mathrm{II}, \mathrm{IIII}} 2(p-\mathrm{BDC})_{2} \mathrm{Cl}\right]_{\mathrm{n}}$ & 13.5 & \multirow{2}{*}{4} & $5.38^{2}$ & 1.34 & \multirow{2}{*}{$>420$} & \\
\hline$\left[\mathrm{Ru}^{\mathrm{II}, \mathrm{IIII}} 2(\mathrm{p}-\mathrm{BDC})_{2} \mathrm{Br}\right]_{\mathrm{n}}$ & 46.7 & & $18.7^{2}$ & 4.67 & & \\
\hline Ti-MOF- $\mathrm{NH}_{2} @ \mathrm{Pt}$ & 11.7 & 3 & $1.17^{2}$ & 0.39 & $>420$ & [49] \\
\hline Ti-MOF-NH $\mathrm{N}_{2} @ \mathrm{Pt}$ & 15.5 & 3 & $1.5^{2}$ & 0.5 & $>420$ & \multirow{3}{*}{$\begin{array}{l}{[50]} \\
{[51]}\end{array}$} \\
\hline $\mathrm{NH}_{2}-\mathrm{UiO}-66(\mathrm{Zr})$ & 107.1 & \multirow[b]{2}{*}{3} & $2.38^{2}$ & 0.93 & \multirow{2}{*}{370} & \\
\hline $\mathrm{NH}_{2}-\mathrm{UiO}-66(\mathrm{Zr}) @ \mathrm{Pt}$ & 125 & & $2.77^{2}$ & 0.79 & & \\
\hline MIL-101(Cr)@CdS/Pt & 300 & \multirow[t]{2}{*}{1} & $150^{2}$ & 75.5 & \multirow[t]{2}{*}{$>420$} & \multirow[t]{2}{*}{ [52] } \\
\hline UiO-66(Zr)@Pt & 0.97 & & $19.5^{3}$ & 3.9 & & \\
\hline UiO-66(Zr)@RhB & 0.67 & \multirow[t]{2}{*}{5} & $13.5^{3}$ & 2.7 & \multirow[t]{2}{*}{$>420$} & \multirow[t]{2}{*}[53]{} \\
\hline $\mathrm{UiO}-66(\mathrm{Zr}) @ \mathrm{RhB} / \mathrm{Pt}$ & 1.4 & & $28^{3}$ & 5.6 & & \\
\hline $\mathrm{UiO}-67\left[\operatorname{Ir}(\mathrm{ppy})_{2}(\mathrm{bpy})\right] @ \mathrm{Pt}$ & 64.8 & 6 & $1620^{1}$ & 270 & 420 & {$[54]$} \\
\hline MOF-253-Pt & 3000 & 34 & $5.6^{1}$ & 0.17 & 420 & [55] \\
\hline UiO-66-[FeFe](dcbdt) $(\mathrm{CO})_{6}$ & 3.5 & 2.5 & $0.7^{2}$ & 0.28 & 470 & [56] \\
\hline$\left\{\left[\mathrm{Sm}_{2} \mathrm{Cu}_{5}(\mathrm{OH})_{2}(\text { pydc })_{6}\left(\mathrm{H}_{2} \mathrm{O}\right)_{8}\right] \cdot \mathrm{I}_{8}\right\}$ & 979.0 & \multirow{4}{*}{5} & $9790^{3}$ & 1958.0 & \multirow{4}{*}{420} & \multirow{4}{*}{ [57] } \\
\hline$\left\{\left[\mathrm{Eu}_{2} \mathrm{Cu}_{5}(\mathrm{OH})_{2}(\text { pydc })_{6}\left(\mathrm{H}_{2} \mathrm{O}\right)_{8}\right] \cdot \mathrm{I}_{8}\right\}$ & 1131.4 & & $11,314^{3}$ & 2262.8 & & \\
\hline$\left\{\left[\mathrm{Gd}_{2} \mathrm{Cu}_{5}(\mathrm{OH})_{2}(\text { pydc })_{6}\left(\mathrm{H}_{2} \mathrm{O}\right)_{8}\right] \cdot \mathrm{I}_{8}\right\}$ & 1025.2 & & $10,252^{3}$ & 2050.4 & & \\
\hline$\left\{\left[\mathrm{Tb}_{2} \mathrm{Cu}_{5}(\mathrm{OH})_{2}(\text { pydc })_{6}\left(\mathrm{H}_{2} \mathrm{O}\right)_{8}\right] \cdot \mathrm{I}_{8}\right\}$ & 1052.5 & & $10,525^{3}$ & 2105.0 & & \\
\hline$(\mathrm{TBA})_{2}\left[\mathrm{Cu}^{\mathrm{II}}(\mathrm{BBTZ})_{2}\left(x-\mathrm{Mo}_{8} \mathrm{O}_{26}\right)\right]$ & 4.68 & 6 & $0.05^{2}$ & 0.008 & $<400$ & \multirow{6}{*}{$\begin{array}{l}{[58]} \\
{[59]}\end{array}$} \\
\hline$\{[\mathrm{AlOH})]_{2} \mathrm{H}_{2} \mathrm{TCPP}\left(\mathrm{DMF}_{3}-\left(\mathrm{H}_{2} \mathrm{O}\right)_{2}\right\}$ & 3.15 & \multirow[t]{5}{*}{8} & $900^{3}$ & 112.5 & 420 & \\
\hline $\multirow[t]{2}{*}{\left[\mathrm{Zn}(\mathrm{bpy})_{3}\right]\left[\mathrm{NaRu}\left(\mathrm{C}_{2} \mathrm{O}_{4}\right)_{3}\right]}_{\mathrm{n}}$ & 0.36 & & $\begin{array}{c}0.04^{1,3} \\
36^{2}\end{array}$ & $\begin{array}{c}0.005 \\
4.5\end{array}$ & $\geqslant 417$ & \\
\hline & 0.36 & & $\begin{array}{c}0.04^{1,3} \\
36^{2}\end{array}$ & $\begin{array}{c}0.005 \\
4.5\end{array}$ & $\leqslant 366$ & \\
\hline $\multirow[t]{2}{*}{\left[\mathrm{Zn}(\mathrm{bpy})_{3}\right]\left[\mathrm{LiRu}\left(\mathrm{C}_{2} \mathrm{O}_{4}\right)_{3}\right]}_{\mathrm{n}}$ & 0.34 & & $\begin{array}{c}0.03^{1,3} \\
34^{2}\end{array}$ & $\begin{array}{c}0.004 \\
4.25\end{array}$ & $\geqslant 417$ & \\
\hline & 0.65 & & $\begin{array}{c}0.06^{1,3} \\
65^{2}\end{array}$ & $\begin{array}{c}0.007 \\
8.12\end{array}$ & $\leqslant 366$ & \\
\hline $\multirow[t]{2}{*}{\left[\mathrm{Cu}(\mathrm{bpy})_{3}\right]\left[\mathrm{NaRu}\left(\mathrm{C}_{2} \mathrm{O}_{4}\right)_{3}\right]}_{\mathrm{n}}$ & 0.30 & \multirow[t]{12}{*}{8} & $\begin{array}{c}0.03^{1,3} \\
30^{2}\end{array}$ & $\begin{array}{c}0.004 \\
3.75\end{array}$ & $\geqslant 417$ & \multirow[t]{12}{*}{ This work } \\
\hline & 0.30 & & $\begin{array}{c}0.03^{1,3} \\
30^{2}\end{array}$ & $\begin{array}{c}0.004 \\
3.75\end{array}$ & $\leqslant 366$ & \\
\hline $\multirow[t]{2}{*}{\left[\mathrm{Cu}(\mathrm{bpy})_{3}\right]\left[\mathrm{LiRu}\left(\mathrm{C}_{2} \mathrm{O}_{4}\right)_{3}\right]}_{\mathrm{n}}$ & 0.39 & & $\begin{array}{c}0.04^{1,3} \\
39^{2}\end{array}$ & $\begin{array}{c}0.005 \\
4.87\end{array}$ & $\geqslant 417$ & \\
\hline & 0.35 & & $\begin{array}{c}0.04^{1,3} \\
35^{2}\end{array}$ & $\begin{array}{c}0.004 \\
4.37\end{array}$ & $\leqslant 366$ & \\
\hline $\multirow[t]{2}{*}{\left[\mathrm{Ru}(\mathrm{bpy})_{3}\right]\left[\mathrm{NaRu}\left(\mathrm{C}_{2} \mathrm{O}_{4}\right)_{3}\right]}_{\mathrm{n}}$ & 0.45 & & $\begin{array}{c}0.04^{1,3} \\
45^{2}\end{array}$ & $\begin{array}{c}0.005 \\
5.62\end{array}$ & $\geqslant 417$ & \\
\hline & 0.71 & & $\begin{array}{c}0.07^{1,3} \\
71^{2}\end{array}$ & $\begin{array}{c}0.009 \\
8.75\end{array}$ & $\leqslant 366$ & \\
\hline $\multirow[t]{2}{*}{\left[\mathrm{Ru}(\mathrm{bpy})_{3}\right]\left[\mathrm{LiRu}\left(\mathrm{C}_{2} \mathrm{O}_{4}\right)_{3}\right]}_{\mathrm{n}}$ & 0.52 & & $\begin{array}{c}0.05^{1,3} \\
52^{2}\end{array}$ & $\begin{array}{c}0.006 \\
6.5\end{array}$ & $\geqslant 417$ & \\
\hline & 0.83 & & $\begin{array}{c}0.08^{1,3} \\
83^{2}\end{array}$ & $\begin{array}{l}0.01 \\
10.4\end{array}$ & $\leqslant 366$ & \\
\hline $\multirow[t]{2}{*}{\left[\mathrm{Os}(\mathrm{bpy})_{3}\right]\left[\mathrm{NaRu}\left(\mathrm{C}_{2} \mathrm{O}_{4}\right)_{3}\right]}_{\mathrm{n}}$ & 0.48 & & $\begin{array}{c}0.05^{1,3} \\
48^{2}\end{array}$ & $\begin{array}{c}0.006 \\
6\end{array}$ & $\geqslant 417$ & \\
\hline & 1.08 & & $\begin{array}{c}0.11^{1,3} \\
108^{2}\end{array}$ & $\begin{array}{l}0.13 \\
13.5\end{array}$ & $\leqslant 366$ & \\
\hline $\multirow[t]{2}{*}{\left[\mathrm{Os}(\mathrm{bpy})_{3}\right]\left[\mathrm{LiRu}\left(\mathrm{C}_{2} \mathrm{O}_{4}\right)_{3}\right]}_{\mathrm{n}}$ & 0.64 & & $\begin{array}{c}0.06^{1,3} \\
64^{2}\end{array}$ & $\begin{array}{c}0.008 \\
8\end{array}$ & $\geqslant 417$ & \\
\hline & 1.23 & & $\begin{array}{c}0.12^{1,3} \\
123^{2}\end{array}$ & $\begin{array}{l}0.15 \\
15.4\end{array}$ & $\leqslant 366$ & \\
\hline
\end{tabular}

${ }^{1} \mathrm{TON}=\mu \mathrm{mol} \mathrm{H} \cdot \mu \mathrm{mol}^{-1} \mathrm{MOF} ;{ }^{2} \mathrm{TON}=\mu \mathrm{mol} \mathrm{H} \cdot \mathrm{mg}^{-1} \mathrm{MOF} ;{ }^{3} \mathrm{TON}=\mu \mathrm{mol} \mathrm{H} \cdot \mathrm{g}^{-1} \mathrm{MOF}$.

According to the proposed mechanism, the resonant energy migration takes place between the $\left[\mathrm{M}^{\mathrm{III}}\left(\mathrm{C}_{2} \mathrm{O}_{4}\right)_{3}\right]^{3-}$ and $\left[\mathrm{Z}^{\mathrm{II} / \mathrm{III}}(\mathrm{bpy})_{3}\right]^{2+/ 3+}$ components of $\left\{\left[\mathrm{Z}^{\mathrm{II} / \mathrm{III}}(\mathrm{bpy})_{3}\right]\left[\mathrm{M}^{\mathrm{I}} \mathrm{M}^{\mathrm{III}}\left(\mathrm{C}_{2} \mathrm{O}_{4}\right)_{3}\right]\right\}_{\mathrm{n}}$, in which energy transfer to the $\left[\mathrm{Z}^{\mathrm{II} / \mathrm{III}}(\mathrm{bpy})_{3}\right]^{2+/ 3+}$ component is more efficient that to $\left[\mathrm{M}^{\mathrm{III}}\left(\mathrm{C}_{2} \mathrm{O}_{4}\right)_{3}\right]^{3-}$. Evidently, the UV region of adsorption of 1-8 consists of the bands attributed to MLCT transition within the $\left\{\left[\mathrm{M}^{\mathrm{I}} \mathrm{Ru}\left(\mathrm{C}_{2} \mathrm{O}_{4}\right)_{3}\right]^{3-}\right\}_{n}$ network, which indicates that under UV-light, the $\left[\mathrm{Ru}\left(\mathrm{C}_{2} \mathrm{O}_{4}\right)_{3}\right]^{3-}$ unit behaves as the photosensitive component, efficiently transferring the energy received upon excitation to $\left[\mathrm{Z}^{\mathrm{II}}(\mathrm{bpy})_{3}\right]^{2+}$ guests $\left(\mathrm{Z}^{\mathrm{II}}=\mathrm{Zn}^{2+}, \mathrm{Cu}^{2+}, \mathrm{Ru}^{2+}, \mathrm{Os}^{2+}\right)$, leading to better photocatalytic performances. 
Meanwhile, the VIS region of 1-8 consists of absorption bands attributed to MLCT transitions within the $\left[\mathrm{Z}^{\mathrm{II}}(\mathrm{bpy})_{3}\right]^{2+}$ component of the coordination polymers, which suggests that tris-bipyridine guests are photosensitive components towards VIS light. Besides the low rate of energy transfer efficiency from the $\left[\mathrm{Z}^{\mathrm{II}}(\mathrm{bpy})_{3}\right]^{2+}$ to $\left[\mathrm{Ru}\left(\mathrm{C}_{2} \mathrm{O}_{4}\right)_{3}\right]^{3-}$ components of the 1-8 frameworks, this leads to the decreasing of the photocatalytic performance in the water-splitting reaction.

Taking into account the above-mentioned statements, we can propose that the reaction includes the following steps: promotion of the $\left[\mathrm{Ru}^{\mathrm{III}}\left(\mathrm{C}_{2} \mathrm{O}_{4}\right)_{3}\right]^{3-}$ structural unit of the framework to its excited state under UV light irradiation; resonant energy migration from the exited $\left(\left[\mathrm{Ru}^{\mathrm{III}}\left(\mathrm{C}_{2} \mathrm{O}_{4}\right)_{3}\right]^{3-}\right)^{*}$ unit to $\left[\mathrm{Z}^{\mathrm{II}}(\mathrm{bpy})_{3}\right]^{2+}$ cationic guest through Forster and Dexter energy transfer mechanisms (see the additional references in the Supplementary Materials), causing the latter to go into the exited state; the exited species $\left(\left[\mathrm{Z}^{\mathrm{II}}(\mathrm{bpy})_{3}\right]^{2+}\right)^{*}$ transfers an electron, located on one bpy ligand, to the water proton and returns to its initial state through the oxidation of a sacrificial reductant TEA.

In order to confirm the recyclability of photocatalysts, the photocatalytic reaction of reductive water splitting was repeated four times with Compound 6, where after each catalytic cycle, the heterogeneous solid was separated by centrifugation, washed several times with distillated water and reused in the next consecutive photocatalytic run. As shown in Figure S17, the amounts of $\mathrm{H}_{2}$ evolved after $8 \mathrm{~h}$ of UV light irradiation in each consecutive photocatalytic cycle decrease slightly, probably due to the loss of catalyst upon recycling manipulation procedures. Moreover, the closely similar photocatalytic activities of recycled catalyst suggest that Compound 6 does not undergo photodecomposition or deactivation, at least after four repeated catalytic runs. Additionally, to confirm the stability of heterogeneous catalyst, after each recycling run, the reused material 6 was checked by $\mathrm{XRD}$, and as evidenced from the comparison of those diffractograms (Figure S18), photocatalyst 6 maintains its crystallinity and structural integrity during the water splitting reaction. These results indicate that coordination polymers 1-8 behave as stable, active and reusable heterogeneous catalysts for the photoreductive water-splitting reaction. Moreover, we compare the photocatalytic activities of 1-8 with other known MOFs and CPs able to photo-split water to $\mathrm{H}_{2}$ (Table 2).

The presented results reveal that coordination polymers $\mathbf{1}-\mathbf{8}$ show moderate photocatalytic activity towards $\mathrm{H}_{2}$ generation under VIS light compared to known MOFs/CPs; meanwhile, under UV light, they exhibit higher photocatalytic efficiencies. It is reasonable to conclude that $\left.\left\{\mathrm{M}^{\mathrm{I}} \mathrm{Ru}\left(\mathrm{C}_{2} \mathrm{O}_{4}\right)_{3}\right]^{2-}\right\}_{\mathrm{n}}$ $\left(\mathrm{M}^{\mathrm{I}}=\mathrm{Na}, \mathrm{Li}\right)$ anionic frameworks selectively templated by $\left[\mathrm{Z}^{\mathrm{II}}(\mathrm{bpy})_{3}\right]^{2+}\left(\mathrm{Z}^{\mathrm{II}}=\mathrm{Zn}^{2+}, \mathrm{Cu}^{2+}, \mathrm{Ru}^{2+}\right.$, $\left.\mathrm{Os}^{2+}\right)$ cationic complexes can be viewed as designable and efficient heterogeneous catalysts for UV light-promoted photoreactions.

\section{Conclusions}

A series of $\left[\mathrm{Z}^{\mathrm{II}}(\mathrm{bpy})_{3}\right]^{2+}$-templated $\left(\mathrm{Z}^{\mathrm{II}}=\mathrm{Zn}^{2+}(\mathbf{1}, \mathbf{2}) ; \mathrm{Cu}^{2+}(\mathbf{3}, \mathbf{4}) ; \mathrm{Ru}^{2+}(5,6) ; \mathrm{Os}^{2+}(7,8)\right)$ and $\left\{\left[\mathrm{M}^{\mathrm{I}} \mathrm{Ru}\left(\mathrm{C}_{2} \mathrm{O}_{4}\right)_{3}\right]^{2-}\right\}_{\mathrm{n}}\left(\mathrm{M}^{\mathrm{I}}=\mathrm{Na}^{+}, \mathrm{Li}^{+}\right)$anionic frameworks were obtained through self-assembly at room temperature in aqueous media. The anionic framework structures of 1-8 consist of triangular cages, which selectively and homogeneously encapsulate $\left[\mathrm{Z}^{\mathrm{II}}(\mathrm{bpy})_{3}\right]^{2+}$ complex cations. Furthermore, the electronic configuration of the cationic guest complexes is shown to be influenced by the framework. In addition, the $\left[\mathrm{Z}^{\mathrm{II}}(\mathrm{bpy})_{3}\right]^{2+}$ templates embedded within the anionic cages of $\left\{\left[\mathrm{M}^{\mathrm{I}} \mathrm{Ru}\left(\mathrm{C}_{2} \mathrm{O}_{4}\right)_{3}\right]^{2-}\right\}_{\mathrm{n}}$ $\left(\mathrm{M}^{\mathrm{I}}=\mathrm{Na}^{+}, \mathrm{Li}^{+}\right)$networks undergo a $6.9 \%-14.4 \%$ expansion as a result of the electrostatic interaction between them. The MLCT band gaps in 1-8 can easily be tuned by the $\left[\mathrm{Z}^{\mathrm{II}}(\mathrm{bpy})_{3}\right]^{2+}$ cationic guest and, as has been shown, follow the order of $3 \approx 4>1>2>5 \sim 6>7 \approx 8$. The 1-8 CPs exhibit catalytic activity in UV light-promoted $\mathrm{H}_{2}$ evolution from water, reaching a total TON of 123 , where photocatalytic efficiencies follow the order $8>7>6>5>2>1 \approx 4>3$. Under VIS light irradiation, the CPs 1-8 exhibit moderate photocatalytic activities, as compared to known MOFs/CPs, with an enhanced catalytic rate following the order of $8>6>7>5>4>1 \approx 2>3$, leading to the production of $\mathrm{H}_{2}$ with a total TON of 64 . Moreover, heterogeneous catalysts remain active for four consecutive usages and preserve the structural integrity and crystallinity. 
These results highlight that rational synthesis of 3D anionic architectures using a target cationic guest, such as $\left[\mathrm{Z}^{\mathrm{II}}(\mathrm{bpy})_{3}\right]^{2+}$, provides a powerful route for the construction of multifunctional guest-encapsulated CPs with a predictable structural topology and desirable properties.

Supplementary Materials: The supplementary materials are available online at www.mdpi.com/2073-4360/8/2/ 48/s1.

Acknowledgments: The authors thank FEDER and Spanish MINECO for financial support under Projects MAT2013-40950-R, UCAN08-4E-008, MAT2012-38664-C02-1 and Consolider ORFEO. Alla Dikhtiarenko also thanks the Spanish Ministerio de Educación, Cultura y Deporte for their pre-doctoral FPU grant (AP2008-03942). We would like to thank Jorge Gascon for fruitful discussions and valuable suggestions during the preparation of the manuscript.

Author Contributions: Alla Dikhtiarenko designed the experiments and performed the syntheses and basic analyses. Rafael Valiente and Pedro Villanueva-Delgado performed UV-Vis measurements and interpreted the data. José R. García and José Gimeno supervised the research work. Alla Dikhtiarenko, José R. García and José Gimeno wrote the paper. All authors were involved in reading and approving the final manuscript.

Conflicts of Interest: The authors declare no conflict of interest.

\section{Abbreviations}

The following abbreviations are used in this manuscript:

$\begin{array}{ll}\text { CPs } & \text { Coordination polymers } \\ \text { MOFs } & \text { Metal-organic frameworks } \\ \text { BDC } & \text { Benzene-1,4-dicarboxylate } \\ \text { bpy } & \text { 2,2'--Bipyridine } \\ \text { EDTA } & \text { Ethylenediaminetetraacetate } \\ \text { MV }^{2+} & \text { N,N'-Dimethyl-4,4'-bipyridinium } \\ \text { ppy } & \text { 2-Phenylpyridine } \\ \text { dcbdt } & \text { 1,4-Dicarboxylbenzene-2,3-dithiolate } \\ \text { TBA } & \text { Tetrabutylammonium cation } \\ \text { BBTZ } & \text { 1,4-bis(1,2,4-Triazol-1-ylmethyl)-benzene } \\ \text { H2TCPP } & \text { Tetra(4-carboxyl-phenyl)porphyrin } \\ \text { SEM } & \text { Scanning electron microscopy } \\ \text { TGA } & \text { Thermogravimetric analysis } \\ \text { XRD } & \text { X-ray diffraction } \\ \text { TEA } & \text { Triethylamine } \\ \text { 3D } & \text { Three-dimensional } \\ \text { SBU } & \text { Secondary building unit } \\ \text { SDTA } & \text { Simultaneous difference thermal analysis } \\ \text { DSC } & \text { Differential scanning calorimetry } \\ \text { MLCT } & \text { Metal-to-ligand charge transfer }\end{array}$

\section{References}

1. Moniz, S.J.A.; Shevlin, S.A.; Martin, D.J.; Guo, Z.-X.; Tang, J. Visible-light driven heterojunction photocatalysts for water splitting-A critical review. Energ. Environ. Sci. 2015, 8, 731-759. [CrossRef]

2. Kudo, A.; Miseki, Y. Heterogeneous photocatalyst materials for water splitting. Chem. Soc. Rev. 2009, 38, 253-278. [CrossRef] [PubMed]

3. Horiuchi, Y.; Toyao, T.; Takeuchi, M.; Matsuoka, M.; Anpo, M. Recent advances in visible-light-responsive photocatalysts for hydrogen production and solar energy conversion-From semiconducting $\mathrm{TiO}_{2}$ to MOF/PCP photocatalysts. Phys. Chem. Chem. Phys. 2013, 15, 13243-13253. [CrossRef] [PubMed]

4. Wei, X.; Wang, K.-X.; Guo, X.-X.; Chen, J.-S. Single-site photocatalysts with a porous structure. Proc. R. Soc. A 2012, 468, 2099-2112. [CrossRef] 
5. Stuart, B.R.; Neil, C.R.; Chen, X.-M.; Garcia-Martinez, J.; Kitagawa, S.; Öhrström, L.; O’Keeffe, M.; Paik Suh, M.; Reedijk, J. Terminology of metal-organic frameworks and coordination polymers (IUPAC recommendations 2013). Pure Appl. Chem. 2013, 85, 1715-1724.

6. Kitagawa, S.; Kitaura, R.; Noro, S.-I. Functional porous coordination polymers. Angew. Chem. Int. Ed. 2004, 43, 2334-2375. [CrossRef] [PubMed]

7. Yaghi, O.M.; O'Keeffe, M.; Ockwig, N.W.; Chae, H.K.; Eddaoudi, M.; Kim, J. Reticular synthesis and the design of new materials. Nature 2003, 423, 705-714. [CrossRef] [PubMed]

8. Li, J.-R.; Kuppler, R.J.; Zhou, H.-C. Selective gas adsorption and separation in metal-organic frameworks. Chem. Soc. Rev. 2009, 38, 1477-1504. [CrossRef] [PubMed]

9. Corma, A.; García, H.; Llabrés i Xamena, F.X. Engineering metal organic frameworks for heterogeneous catalysis. Chem. Rev. 2010, 110, 4606-4655. [CrossRef] [PubMed]

10. Zhang, W.; Xiong, R.-G. Ferroelectric metal-organic frameworks. Chem. Rev. 2012, 112, 1163-1195. [CrossRef] [PubMed]

11. Yamada, T.; Otsubo, K.; Makiura, R.; Kitagawa, H. Designer coordination polymers: Dimensional crossover architectures and proton conduction. Chem. Soc. Rev. 2013, 42, 6655-6669. [CrossRef] [PubMed]

12. Gascon, J.; Corma, A.; Kapteijn, F.; Llabrés i Xamena, F.X. Metal organic framework catalysis: Quo vadis? ACS Catal. 2014, 4, 361-378. [CrossRef]

13. Ramaswamy, P.; Wong, N.E.; Shimizu, G.K.H. MOFs as proton conductors-Challenges and opportunities. Chem. Soc. Rev. 2014, 43, 5913-5932. [CrossRef] [PubMed]

14. Alvaro, M.; Carbonell, E.; Ferrer, B.; Llabrés i Xamena, F.X.; Garcia, H. Semiconductor behavior of a metal-organic framework (MOF). Chem. Eur. J. 2007, 13, 5106-5112. [CrossRef] [PubMed]

15. Llabrés i Xamena, F.X.; Corma, A.; Garcia, H. Applications for metal-organic frameworks (MOFs) as quantum dot semiconductors. J. Phys. Chem. C 2007, 111, 80-85. [CrossRef]

16. Wang, J.-L.; Wang, C.; Lin, W. Metal-organic frameworks for light harvesting and photocatalysis. ACS Catal. 2012, 2, 2630-2640. [CrossRef]

17. Nasalevich, M.A.; van der Veen, M.; Kapteijn, F.; Gascon, J. Metal-organic frameworks as heterogeneous photocatalysts: Advantages and challenges. Cryst. Eng. Comm. 2014, 16, 4919-4926. [CrossRef]

18. Zhang, T.; Lin, W. Metal-organic frameworks for artificial photosynthesis and photocatalysis. Chem. Soc. Rev. 2014, 43, 5982-5993. [CrossRef] [PubMed]

19. Wang, C.; Xie, Z.; deKrafft, K.E.; Lin, W. Doping metal-organic frameworks for water oxidation, carbon dioxide reduction, and organic photocatalysis. J. Am. Chem. Soc. 2011, 133, 13445-13454. [CrossRef] [PubMed]

20. Wang, S.; Yao, W.; Lin, J.; Ding, Z.; Wang, X. Cobalt imidazolate metal-organic frameworks photosplit $\mathrm{CO}_{2}$ under mild reaction conditions. Angew. Chem. Int. Ed. 2014, 53, 1034-1038. [CrossRef] [PubMed]

21. Fu, Y.; Sun, D.; Chen, Y.; Huang, R.; Ding, Z.; Fu, X.; Li, Z. An amine-functionalized titanium metal-organic framework photocatalyst with visible-light-induced activity for $\mathrm{CO}_{2}$ reduction. Angew. Chem. Int. Ed. 2012, 51, 3364-3367. [CrossRef] [PubMed]

22. Sun, D.; Fu, Y.; Liu, W.; Ye, L.; Wang, D.; Yang, L.; Fu, X.; Li, Z. Studies on photocatalytic $\mathrm{CO}_{2}$ reduction over $\mathrm{NH}_{2}-\mathrm{UiO}-66(\mathrm{Zr})$ and its derivatives: Towards a better understanding of photocatalysis on metal-organic frameworks. Chem. Eur. J. 2013, 19, 14279-14285. [CrossRef] [PubMed]

23. Sun, D.; Liu, W.; Fu, Y.; Fang, Z.; Sun, F.; Fu, X.; Zhang, Y.; Li, Z. Noble metals can have different effects on photocatalysis over metal-organic frameworks (MOFs): A case study on $\mathrm{M} / \mathrm{NH}_{2}-\mathrm{MIL}-125$ (Ti) (M=Pt and Au). Chem. Eur. J. 2014, 20, 4780-4788. [CrossRef] [PubMed]

24. Li, J.; Luo, D.; Yang, C.; He, S.; Chen, S.; Lin, J.; Zhu, L.; Li, X. Copper(II) imidazolate frameworks as highly efficient photocatalysts for reduction of $\mathrm{CO}_{2}$ into methanol under visible light irradiation. J. Solid State Chem. 2013, 203, 154-159. [CrossRef]

25. Liu, Y.; Yang, Y.; Sun, Q.; Wang, Z.; Huang, B.; Dai, Y.; Qin, X.; Zhang, X. Chemical adsorption enhanced $\mathrm{CO}_{2}$ capture and photoreduction over a copper porphyrin based metal organic framework. ACS Appl. Mater. Interfaces 2013, 5, 7654-7658. [CrossRef] [PubMed]

26. Han, S.; Wei, Y.; Grzybowski, B.A. A metal-organic framework stabilizes an occluded photocatalyst. Chem. Eur. J. 2013, 19, 11194-11198. [CrossRef] [PubMed] 
27. Ameloot, R.; Roeffaers, M.B.J.; De Cremer, G.; Vermoortele, F.; Hofkens, J.; Sels, B.F.; De Vos, D.E. Metal-organic framework single crystals as photoactive matrices for the generation of metallic microstructures. Adv. Mater. 2011, 23, 1788-1791. [CrossRef] [PubMed]

28. Choi, J.R.; Tachikawa, T.; Fujitsuka, M.; Majima, T. Europium-based metal-organic framework as a photocatalyst for the one-electron oxidation of organic compounds. Langmuir 2010, 26, 10437-10443. [CrossRef] [PubMed]

29. Laurier, K.G.M.; Vermoortele, F.; Ameloot, R.; De Vos, D.E.; Hofkens, J.; Roeffaers, M.B.J. Iron(III)-based metal-organic frameworks as visible light photocatalysts. J. Am. Chem. Soc. 2013, 135, 14488-14491. [CrossRef] [PubMed]

30. Shen, L.; Liang, S.; Wu, W.; Liang, R.; Wu, L. CdS-decorated UiO-66 $\left(\mathrm{NH}_{2}\right)$ nanocomposites fabricated by a facile photodeposition process: An efficient and stable visible-light-driven photocatalyst for selective oxidation of alcohols. J. Mater. Chem. A 2013, 1, 11473-11482. [CrossRef]

31. Shen, L.; Liang, S.; Wu, W.; Liang, R.; Wu, L. Multifunctional $\mathrm{NH}_{2}$-mediated zirconium metal-organic framework as an efficient visible-light-driven photocatalyst for selective oxidation of alcohols and reduction of aqueous Cr(VI). Dalton Trans. 2013, 42, 13649-13657. [CrossRef] [PubMed]

32. Xie, M.-H.; Yang, X.-L.; Zou, C.; Wu, C.-D. A SnIV-porphyrin-based metal-organic framework for the selective photo-oxygenation of phenol and sulfides. Inorg. Chem. 2011, 50, 5318-5320. [CrossRef] [PubMed]

33. Fu, H.-R.; Kang, Y.; Zhang, J. Highly selective sorption of small hydrocarbons and photocatalytic properties of three metal-organic frameworks based on Tris(4-(1h-imidazol-1-yl)phenyl)amine ligand. Inorg. Chem. 2014, 53, 4209-4214. [CrossRef] [PubMed]

34. Gao, J.; Miao, J.; Li, P.-Z.; Teng, W.Y.; Yang, L.; Zhao, Y.; Liu, B.; Zhang, Q. A p-type Ti(IV)-based metal-organic framework with visible-light photo-response. Chem. Commun. 2014, 50, 3786-3788. [CrossRef] [PubMed]

35. Mahata, P.; Madras, G.; Natarajan, S. Novel photocatalysts for the decomposition of organic dyes based on metal-organic framework compounds. J. Phys. Chem. B 2006, 110, 13759-13768. [CrossRef] [PubMed]

36. Xu, W.-T.; Ma, L.; Ke, F.; Peng, F.-M.; Xu, G.-S.; Shen, Y.-H.; Zhu, J.-F.; Qiu, L.-G.; Yuan, Y.-P. Metal-organic frameworks MIL-88A hexagonal microrods as a new photocatalyst for efficient decolorization of methylene blue dye. Dalton Trans. 2014, 43, 3792-3798. [CrossRef] [PubMed]

37. Zhang, S.; Han, L.; Li, L.; Cheng, J.; Yuan, D.; Luo, J. A highly symmetric metal-organic framework based on a propeller-like Ru-organic metalloligand for photocatalysis and explosives detection. Cryst. Growth Des. 2013, 13, 5466-5472. [CrossRef]

38. Long, J.; Wang, S.; Ding, Z.; Wang, S.; Zhou, Y.; Huang, L.; Wang, X. Amine-functionalized zirconium metal-organic framework as efficient visible-light photocatalyst for aerobic organic transformations. Chem. Commun. 2012, 48, 11656-11658. [CrossRef] [PubMed]

39. Toyao, T.; Saito, M.; Horiuchi, Y.; Matsuoka, M. Development of a novel one-pot reaction system utilizing a bifunctional Zr-based metal-organic framework. Catal. Sci. Technol. 2014, 4, 625-628. [CrossRef]

40. Wu, P.; He, C.; Wang, J.; Peng, X.; Li, X.; An, Y.; Duan, C. Photoactive chiral metal-organic frameworks for light-driven asymmetric $\alpha$-alkylation of aldehydes. J. Am. Chem. Soc. 2012, 134, 14991-14999. [CrossRef] [PubMed]

41. Gascon, J.; Hernández-Alonso, M.D.; Almeida, A.R.; van Klink, G.P.M.; Kapteijn, F.; Mul, G. Isoreticular mofs as efficient photocatalysts with tunable band gap: An operando FTIR study of the photoinduced oxidation of propylene. ChemSusChem 2008, 1, 981-983. [CrossRef] [PubMed]

42. Nasalevich, M.A.; Goesten, M.G.; Savenije, T.J.; Kapteijn, F.; Gascon, J. Enhancing optical absorption of metal-organic frameworks for improved visible light photocatalysis. Chem. Commun. 2013, 49, 10575-10577. [CrossRef] [PubMed]

43. Lin, C.-K.; Zhao, D.; Gao, W.-Y.; Yang, Z.; Ye, J.; Xu, T.; Ge, Q.; Ma, S.; Liu, D.-J. Tunability of band gaps in metal-organic frameworks. Inorg. Chem. 2012, 51, 9039-9044. [CrossRef] [PubMed]

44. Yang, L.-M.; Fang, G.-Y.; Ma, J.; Ganz, E.; Han, S.S. Band gap engineering of paradigm MOF-5. Cryst. Growth Des. 2014, 14, 2532-2541. [CrossRef]

45. Meyer, K.; Ranocchiari, M.; van Bokhoven, J.A. Metal organic frameworks for photo-catalytic water splitting. Energ. Environ. Sci. 2015, 8, 1923-1937. [CrossRef]

46. Ren, Y.; Chia, G.H.; Gao, Z. Metal-organic frameworks in fuel cell technologies. Nano Today 2013, 8, 577-597. [CrossRef] 
47. Kataoka, Y.; Sato, K.; Miyazaki, Y.; Masuda, K.; Tanaka, H.; Naito, S.; Mori, W. Photocatalytic hydrogen production from water using porous material $\left[\mathrm{Ru}_{2}(\mathrm{p}-\mathrm{BDC})_{2}\right]_{n}$. Energ. Environ. Sci. 2009, 2, 397-400. [CrossRef]

48. Kataoka, Y.; Miyazaki, Y.; Sato, K.; Saito, T.; Nakanishi, Y.; Kiatagwa, Y.; Kawakami, T.; Okumura, M.; Yamaguchi, K.; Mori, W. Modification of MOF catalysts by manipulation of counter-ions: Experimental and theoretical studies of photochemical hydrogen production from water over microporous diruthenium (II, III) coordination polymers. Supramol. Chem. 2011, 23, 287-296. [CrossRef]

49. Horiuchi, Y.; Toyao, T.; Saito, M.; Mochizuki, K.; Iwata, M.; Higashimura, H.; Anpo, M.; Matsuoka, M. Visible-light-promoted photocatalytic hydrogen production by using an amino-functionalized Ti(IV) metal-organic framework. J. Phys. Chem. C 2012, 116, 20848-20853. [CrossRef]

50. Toyao, T.; Saito, M.; Horiuchi, Y.; Mochizuki, K.; Iwata, M.; Higashimura, H.; Matsuoka, M. Efficient hydrogen production and photocatalytic reduction of nitrobenzene over a visible-light-responsive metal-organic framework photocatalyst. Catal. Sci. Technol. 2013, 3, 2092-2097. [CrossRef]

51. Gomes Silva, C.; Luz, I.; Llabrés i Xamena, F.X.; Corma, A.; García, H. Water stable Zr-benzenedicarboxylate metal-organic frameworks as photocatalysts for hydrogen generation. Chem. Eur. J. 2010, 16, 11133-11138. [CrossRef] [PubMed]

52. He, J.; Yan, Z.; Wang, J.; Xie, J.; Jiang, L.; Shi, Y.; Yuan, F.; Yu, F.; Sun, Y. Significantly enhanced photocatalytic hydrogen evolution under visible light over $\mathrm{CdS}$ embedded on metal-organic frameworks. Chem. Commun. 2013, 49, 6761-6763. [CrossRef] [PubMed]

53. He, J.; Wang, J.; Chen, Y.; Zhang, J.; Duan, D.; Wang, Y.; Yan, Z. A dye-sensitized Pt@UiO-66(Zr) metal-organic framework for visible-light photocatalytic hydrogen production. Chem. Commun. 2014, 50, 7063-7066. [CrossRef] [PubMed]

54. Wang, C.; de Krafft, K.E.; Lin, W. Pt nanoparticles@photoactive metal-organic frameworks: Efficient hydrogen evolution via synergistic photoexcitation and electron injection. J. Am. Chem. Soc. 2012, 134, 7211-7214. [CrossRef] [PubMed]

55. Zhou, T.; Du, Y.; Borgna, A.; Hong, J.; Wang, Y.; Han, J.; Zhang, W.; Xu, R. Post-synthesis modification of a metal-organic framework to construct a bifunctional photocatalyst for hydrogen production. Energ. Environ. Sci. 2013, 6, 3229-3234. [CrossRef]

56. Pullen, S.; Fei, H.; Orthaber, A.; Cohen, S.M.; Ott, S. Enhanced photochemical hydrogen production by a molecular diiron catalyst incorporated into a metal-organic framework. J. Am. Chem. Soc. 2013, 135, 16997-17003. [CrossRef] [PubMed]

57. Hu, X.-L.; Sun, C.-Y.; Qin, C.; Wang, X.-L.; Wang, H.-N.; Zhou, E.-L.; Li, W.-E.; Su, Z.-M. Iodine-templated assembly of unprecedented $3 \mathrm{D}-4 \mathrm{~F}$ metal-organic frameworks as photocatalysts for hydrogen generation. Chem. Commun. 2013, 49, 3564-3566. [CrossRef] [PubMed]

58. Fu, H.; Qin, C.; Lu, Y.; Zhang, Z.-M.; Li, Y.-G.; Su, Z.-M.; Li, W.-L.; Wang, E.-B. An ionothermal synthetic approach to porous polyoxometalate-based metal-organic frameworks. Angew. Chem. Int. Ed. 2012, 51, 7985-7989. [CrossRef] [PubMed]

59. Fateeva, A.; Chater, P.A.; Ireland, C.P.; Tahir, A.A.; Khimyak, Y.Z.; Wiper, P.V.; Darwent, J.R.; Rosseinsky, M.J. A water-stable porphyrin-based metal-organic framework active for visible-light photocatalysis. Angew. Chem. Int. Ed. 2012, 51, 7440-7444. [CrossRef] [PubMed]

60. Nasalevich, M.A.; Becker, R.; Ramos-Fernandez, E.V.; Castellanos, S.; Veber, S.L.; Fedin, M.V.; Kapteijn, F.; Reek, J.N.H.; van der Vlugt, J.I.; Gascon, J. Co@NH 2 -MIL-125(Ti): Cobaloxime-derived metal-organic framework-based composite for light-driven $\mathrm{H}_{2}$ production. Energ. Environ. Sci. 2015, 8, 364-375. [CrossRef]

61. Decurtins, S.; Schmalle, H.W.; Schneuwly, P.; Ensling, J.; Guetlich, P. A concept for the synthesis of 3-dimensional homo- and bimetallic oxalate-bridged networks $\left[\mathrm{M}_{2}(\mathrm{ox})_{3}\right] \mathrm{n}$. Structural, moessbauer, and magnetic studies in the field of molecular-based magnets. J. Am. Chem. Soc. 1994, 116, 9521-9528. [CrossRef]

62. Milos, M.; Hauser, A. A model for spectral diffusion induced by resonant energy migration applied to the ${ }^{4} \mathrm{~A}_{2} \rightarrow{ }^{2} \mathrm{E}$ transition of $\mathrm{Cr}^{3+}$ in $\left[\mathrm{Cr}(\mathrm{ox})_{3}\right]^{3-}\left(\mathrm{ox}=\mathrm{C}_{2} \mathrm{O}_{4}{ }^{2-}\right)$. J. Lumin. 2009, 129, 1901-1904. [CrossRef]

63. Milos, M.; Hauser, A. Chromium(III)-trisoxalate, a versatile building block for luminescent materials. J. Lumin. 2013, 133, 15-20. [CrossRef]

64. Milos, M.; Penhouet, T.; Pal, P.; Hauser, A. Structural study of mixed crystals of $\left[\mathrm{Zn}_{1-x} \mathrm{Ru}_{x}(\mathrm{bpy})_{3}\right]\left[\mathrm{NaCr}(\mathrm{ox})_{3}\right]$ probed by high-resolution absorption spectroscopy and high-pressure experiments. Inorg. Chem. 2010, 49, 3402-3408. [CrossRef] [PubMed] 
65. Pellaux, R.; Decurtins, S.; Schmalle, H.W. Three anionic polymeric networks: Sodium(I)-ruthenium(III), sodium(I)-rhodium(III) and sodium(I)-aluminium(III) $\mu$-oxalato complexes with Tris(2,2'-bipyridine) ruthenium(II) cations. Acta Crystallogr. Sect. C 1999, 55, 1075-1079. [CrossRef]

66. Rabaste, S.; Amstutz, N.; Hauser, A.; Pillonnet, A. Optical properties of thin films of $\left[\mathrm{Ru}(\mathrm{bpy})_{3}\right]\left[\mathrm{NaCr}(\mathrm{ox})_{3}\right]$ polymeric networks. Appl. Phys. Lett. 2005, 87, 251904. [CrossRef]

67. Roman, P.; Guzman-Miralles, C.; Luque, A. Synthesis, structure and characterisation of $\left[\mathrm{Ni}(\text { bipy })_{3}\right]\left[\mathrm{NaAl}(\mathrm{ox})_{3}\right]:($ bipy = 2,2'-bipyridine, ox = oxalate). J. Chem. Soc. Dalton Trans. 1996. [CrossRef]

68. Sieber, R.; Decurtins, S.; Stoeckli-Evans, H.; Wilson, C.; Yufit, D.; Howard, J.A.K.; Capelli, S.C.; Hauser, A. A thermal spin transition in $\left[\mathrm{Co}(\mathrm{bpy})_{3}\right]\left[\mathrm{LiCr}(\mathrm{ox})_{3}\right]\left(\mathrm{ox}=\mathrm{C}_{2} \mathrm{O}_{4}{ }^{2-} ; \mathrm{bpy}=2,2^{\prime}\right.$-bipyridine). Chem. Eur. J. 2000, 6, 361-368. [CrossRef]

69. Von Arx, M.E.; Burattini, E.; Hauser, A.; van Pieterson, L.; Pellaux, R.; Decurtins, S. Luminescence and energy transfer of $\left[\mathrm{Ru}(\mathrm{bpy})_{3}\right]^{2+},\left[\mathrm{Cr}(\mathrm{ox})_{3}\right]^{3-}$, and $\left[\mathrm{Os}(\mathrm{bpy})_{3}\right]^{2+}$ in three-dimensional oxalato-networks. J. Phys. Chem. A 2000, 104, 883-893. [CrossRef]

70. Von Arx, M.E.; Hauser, A.; Riesen, H.; Pellaux, R.; Decurtins, S. Resonant and phonon-assisted excitation energy transfer in the $\mathrm{R}_{1}$ line of $\left[\mathrm{Cr}(\mathrm{ox})_{3}\right]^{3-}$. Phys. Rev. B 1996, 54, 15800-15807. [CrossRef]

71. Andrés, R.; Gruselle, M.; Malézieux, B.; Verdaguer, M.; Vaissermann, J. Enantioselective synthesis of optically active polymeric homo- and bimetallic oxalate-bridged networks $\left[\mathrm{M}_{2}(\mathrm{ox})_{3}\right] \mathrm{n}$. Inorg. Chem. 1999, 38, 4637-4646. [CrossRef] [PubMed]

72. Decurtins, S.; Schmalle, H.W.; Pellaux, R.; Schneuwly, P.; Hauser, A. Chiral, three-dimensional supramolecular compounds: Homo- and bimetallic oxalate- and 1,2-dithiooxalate-bridged networks. A structural and photophysical study. Inorg. Chem. 1996, 35, 1451-1460. [CrossRef] [PubMed]

73. Hauser, A.; Riesen, H.; Pellaux, R.; Decurtins, S. Resonant excitation energy transfer in $\left[\mathrm{Rh}(\mathrm{bpy})_{3}\right]\left[\mathrm{NaCr}(\mathrm{ox})_{3}\right] \mathrm{ClO}_{4}$. Chem. Phys. Lett. 1996, 261, 313-317. [CrossRef]

74. Langford, V.S.; von Arx, M.E.; Hauser, A. Superexchange and dipole-dipole energy transfer from the $\left[\mathrm{Cr}(\mathrm{ox})_{3}\right]^{3-}$ of 3D oxalate networks to encapsulated $\left[\mathrm{Cr}(\mathrm{bpy})_{3}\right]^{3+}$. J. Phys. Chem. A 1999, 103, 7161-7169. [CrossRef]

75. Milos, M.; Pal, P.; Hauser, A. Effect of external pressure on the excitation energy transfer from $\left[\mathrm{Cr}(\mathrm{ox})_{3}\right]^{3-}$ to $\left[\mathrm{Cr}(\mathrm{bpy})_{3}\right]^{3+}$ in $\left[\mathrm{Rh}_{1-x} \mathrm{Cr}_{\mathrm{x}}(\mathrm{bpy})_{3}\right]\left[\mathrm{NaM}_{1-y} \mathrm{Cr}_{\mathrm{y}}(\mathrm{ox})_{3}\right] \mathrm{ClO}_{4}$. ChemPhysChem 2010, 11, 3161-3166. [CrossRef] [PubMed]

76. Von Arx, M.E.; Langford, V.S.; Oetliker, U.; Hauser, A. Resonant energy transfer in the mixed crystal series $\left[\mathrm{Rh}(\mathrm{bpy})_{3}\right]\left[\mathrm{NaAl}_{x} \mathrm{Cr}_{1-x}(\mathrm{ox})_{3}\right] \mathrm{ClO}_{4}$ (bpy =2,2'-bipyridine, ox = oxalate, $\left.\mathrm{x}=0.05-1\right)$. J. Phys. Chem. A 2002, 106, 7099-7105. [CrossRef]

77. Larsen, R.W.; Wojtas, L. Photophysical studies of Ru(II)tris(2,2'-bipyridine) confined within a Zn(II)-trimesic acid polyhedral metal-organic framework. J. Phys. Chem. A 2012, 116, 7830-7835. [CrossRef] [PubMed]

78. Burstall, F.H.; Dwyer, F.P.; Gyarfas, E.C. 194. Optical activity dependent on a six-covalent bivalent osmium complex. J. Chem. Soc. 1950. [CrossRef]

79. Kaziro, R.; Hambley, T.W.; Binstead, R.A.; Beattie, J.K. Potassium Tris(oxalato)ruthenate (III). Inorg. Chim. Acta 1989, 164, 85-91. [CrossRef]

80. Thornton, D.A.; Watkins, G.M. The infrared spectra $\left(4000-50 \mathrm{~cm}^{-1}\right)$ of complexes of 2,2'-bipyridine, 1,10-phenanthroline and their perdeuterated analogues with metal(II) perchlorates of the first transition series. J. Coord. Chem. 1992, 25, 299-315. [CrossRef]

81. Altomare, A.; Cascarano, G.; Giacovazzo, C.; Guagliardi, A.; Burla, M.C.; Polidori, G.; Camalli, M. SIR92-a program for automatic solution of crystal structures by direct methods. J. Appl. Cryst. 1994, $27,435$. [CrossRef]

82. Sheldrick, G. Crystal structure refinement with shelxl. Acta Crystallogr. Sect. C 2015, 71, 3-8. [CrossRef] [PubMed]

83. Flack, H.D.; Bernardinelli, G. Reporting and evaluating absolute-structure and absolute-configuration determinations. J. Appl. Cryst. 2000, 33, 1143-1148. [CrossRef]

84. Blatov, V.A.; Shevchenko, A.P.; Proserpio, D.M. Applied topological analysis of crystal structures with the program package topospro. Cryst. Growth Des. 2014, 14, 3576-3586. [CrossRef]

85. Hyde, S.T.; O'Keeffe, M.; Proserpio, D.M. A short history of an elusive yet ubiquitous structure in chemistry, materials, and mathematics. Angew. Chem. Int. Ed. 2008, 47, 7996-8000. [CrossRef] [PubMed] 
86. Chen, X.-M.; Wang, R.-Q.; Yu, X.-L. Tris(2,2'-bipyridine)zinc(II) perchlorate. Acta Crystallogr. Sect. C 1995, 51, 1545-1547. [CrossRef]

87. Majumdar, P.; Ghosh, A.K.; Falvello, L.R.; Peng, S.-M.; Goswami, S. Silver(I) assisted metal exchange reaction. A generalized synthesis of tris-chelated copper(II) complexes of neutral N,N-donors. Inorg. Chem. 1998, 37, 1651-1654. [CrossRef]

88. Harrowfield, J.; Sobolev, A. The crystal structure of tris(2,2'-bipyridine)ruthenium(II) perchlorate. Aust. J. Chem. 1994, 47, 763-767. [CrossRef]

89. Richter, M.M.; Scott, B.; Brewer, K.J.; Willett, R.D. Crystal and molecular structure of Tris(2,2'-bipyridyl)osmium(II) bis(hexafluorophosphate). Acta Crystallogr. Sect. C 1991, 47, 2443-2444. [CrossRef]

90. Robinson, K.; Gibbs, G.V.; Ribbe, P.H. Quadratic elongation: A quantitative measure of distortion in coordination polyhedra. Science 1971, 172, 567-570. [CrossRef] [PubMed]

91. Brown, I.D.; Shannon, R.D. Empirical bond-strength-bond-length curves for oxides. Acta Crystallogr. Sect. A 1973, 29, 266-282. [CrossRef]

92. Russell, M.V.; Craig, C.D.; Scudder, L.M.; Dance, G.I. Interpenetrating non-molecular and supramolecular $(10,3)$ - a nets occurring with chiral recognition in crystalline $\left(\mathrm{Ph}_{3} \mathrm{MeP}\right)_{2}\left[\mathrm{NaCr}(\mathrm{ox})_{3}\right]$. Cryst. Eng. Comm. 2000, 2, 16-23. [CrossRef]

93. Baburin, I.A.; Blatov, V.A. Sizes of molecules in organic crystals: The Voronoi-Dirichlet approach. Acta Crystallogr. Sect. B 2004, 60, 447-452. [CrossRef] [PubMed]

94. Olliff, R.W.; Odell, A.L. 454. Correlation of reaction rates with electronic absorption spectra for a series of trisoxalates of tervalent metals. J. Chem. Soc. 1964, 2417-2421. [CrossRef]

95. Lever, A.B.P. Inorganic electronic spectroscopy; Elsevier: Amsterdam, NY, USA, 1984.

96. Palmer, R.A.; Piper, T.S. 2,2'-Bipyridine complexes. I. Polarized crystal spectra of Tris $\left(2,2^{\prime}-\right.$ bipyridine)copper(II), -nickel(II), -cobalt(II), -iron(II), and -ruthenium(II). Inorg. Chem. 1966, 5, 864-878. [CrossRef]

97. Riesen, H.; Wallace, L.; Krausz, E. Localised ${ }^{3} \mathrm{MLCT}$ states of $\left.\left[\mathrm{Ru}(\mathrm{bpy})_{3-x} \text { (phen }\right)_{x}\right]^{2+}(\mathrm{x}=0$ to 3$)$ in racemic [Zn(bpy) $\left.{ }_{3}\right]\left(\mathrm{ClO}_{4}\right)_{2}$. Chem. Phys. Lett. 1994, 228, 605-609. [CrossRef]

98. Otsuka, T.; Takahashi, N.; Fujigasaki, N.; Sekine, A.; Ohashi, Y.; Kaizu, Y. Crystal structure and energy transfer in double-complex salts composed of tris(2,2'-bipyridine)ruthenium(II) or tris(2,2'-bipyridine)osmium(II) and hexacyanochromate(III). Inorg. Chem. 1999, 38, 1340-1347. [CrossRef] [PubMed]

99. Wood, D.L.; Tauc, J. Weak absorption tails in amorphous semiconductors. Phys. Rev. B 1972, 5, 3144-3151. [CrossRef]

100. Larsen, R.W.; Wojtas, L. Photoinduced inter-cavity electron transfer between Ru(II)tris(2,2'-bipyridne) and $\mathrm{Co}(\mathrm{II})$ tris(2,2'-bipyridine) co-encapsulated within a $\mathrm{Zn}$ (II)-trimesic acid metal organic framework. J. Mater. Chem. A 2013, 1, 14133-14139. [CrossRef]

101. Kumura, M.; Yamashita, T.; Nishida, S. Light-induced electron-transfer reactions. Part 2. Kinetics of the intra-molecular redox decomposition of tris(oxalato)-cobaltate(III) by irradiation with visible light of aqueous solution containing tris(2,2'-bipyridine)ruthenium(II) ion. Inorg. Chim. Acta 1984, 89, 193-198. [CrossRef]

102. Decurtins, S.; Pellaux, R. Supramolecular host/guest compounds and their prospects for multifunctional materials. Comments Inorg. Chem. 1998, 20, 143-161. [CrossRef]

(C) 2016 by the authors; licensee MDPI, Basel, Switzerland. This article is an open access article distributed under the terms and conditions of the Creative Commons by Attribution (CC-BY) license (http://creativecommons.org/licenses/by/4.0/). 